Portland State University

PDXScholar

$5-24-2013$

\title{
Classical Political Philosophy and Modern Democracy
}

Rebekkah Brainerd

Portland State University

Follow this and additional works at: https://pdxscholar.library.pdx.edu/honorstheses Let us know how access to this document benefits you.

\section{Recommended Citation}

Brainerd, Rebekkah, "Classical Political Philosophy and Modern Democracy" (2013). University Honors Theses. Paper 22.

https://doi.org/10.15760/honors.17

This Thesis is brought to you for free and open access. It has been accepted for inclusion in University Honors Theses by an authorized administrator of PDXScholar. Please contact us if we can make this document more accessible: pdxscholar@pdx.edu. 


\section{Classical Political Philosophy and Modern Democracy}

by

\section{Rebekkah Brainerd}

An undergraduate honors thesis submitted in partial fulfillment of the

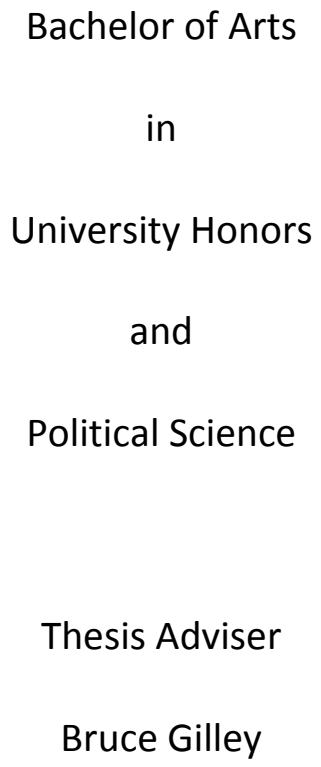

Bachelor of Arts

in

University Honors

and

Political Science

Thesis Adviser

Bruce Gilley

Portland State University 


\title{
Classical Political Philosophy and Modern Democracy \\ An analysis of relevance
}

Rebekkah Brainerd

\begin{abstract}
This paper will be looking at the classical political theories of Plato, Aristotle and Thucydides on democracy to prove they are still relevant and applicable, as well as looking into the problem of democratic corruption. This paper will be split into three sections. The first section will explore these philosophers' theories on different types of constitutions and explore what forms the basis for their theories upon democracy. The second section will develop an applicable "classical political theory on democracy," distilled from these authors' arguments. The final section will be applying classical political theory to contemporary American trends to show how significant these theories are even today. This paper will be proving that, through the eyes of classical political theory, the main problem with democracy is that it has no safeguards against the destructive side of human nature. Because democracy's inherent nature to reflect the will and desires of its citizenry, it ends up being as corruptible as people are. In conclusion, the solutions to problems of democracy have been known all along, but require a level of civic engagement that most citizens are unwilling to give.
\end{abstract}




\section{Table of Contents}

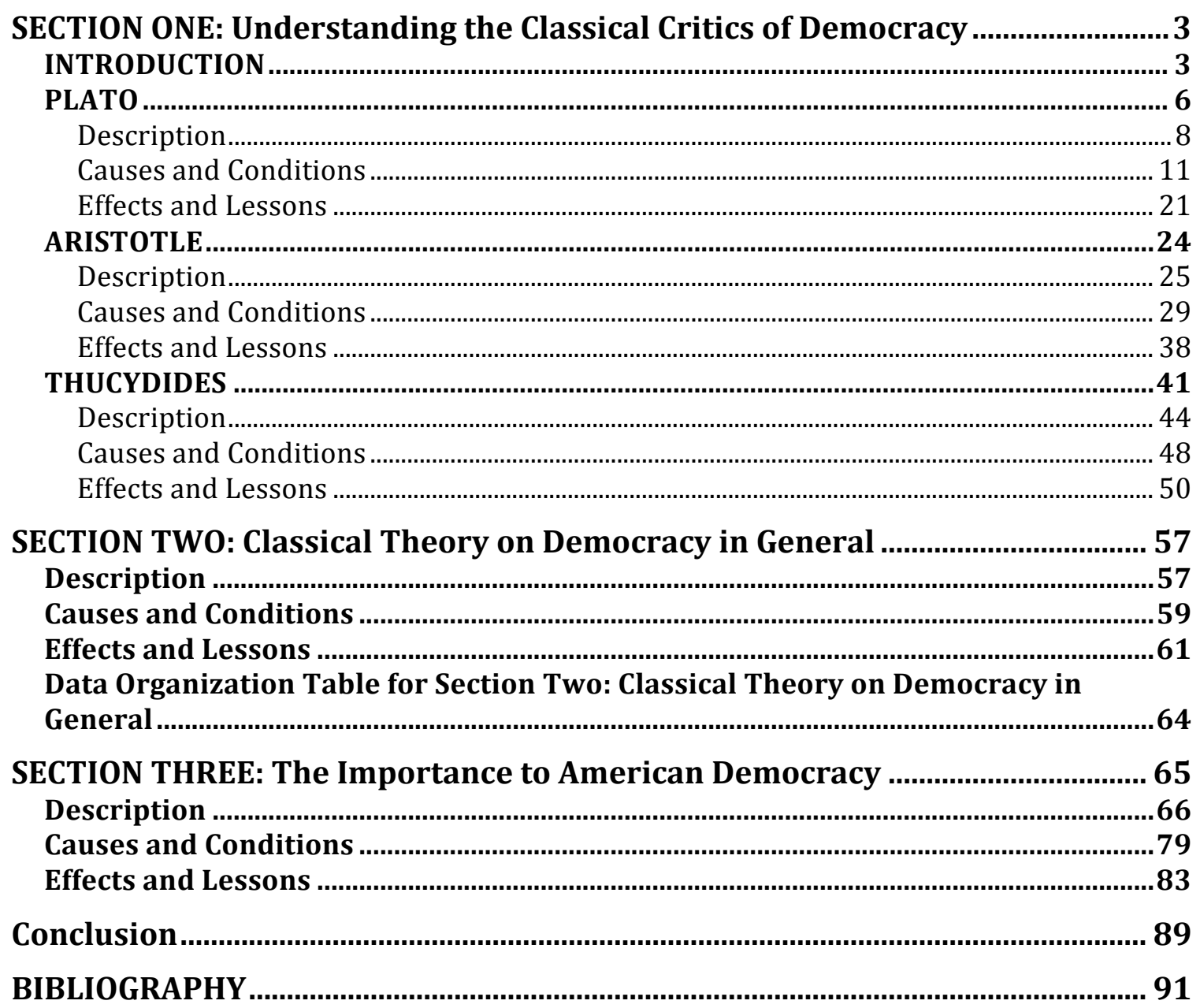




\section{SECTION ONE: Understanding the Classical Critics of Democracy}

\section{INTRODUCTION}

The subject of this paper came by way of an interest in the concept of corruption in democratic regimes and a concern for the health of the American democratic system. Today, the age-old cry of corruption and abuse by government can be heard in almost any forum of media. With this concern, it would seem appropriate to look these claims of corruption and downfall with the facts available to prove either validity or hyperbole. Some may say that these claims of national degradation are false or are an over exaggeration of problems that all regimes face at some time. Other invoke images of Orwell's 1984, control of government by corporations, and a cry for revolution and change.

While some of these claims are brought about by paranoia and prejudice, there is still something that resonates in them. Perhaps it is that the United States was formed on the basis of revolution and change, and that cultural memory still hums within us. Perhaps it is our American liberal heritage, our foundational beliefs in the rights of individuals, and our hostility to anything that is perceived to threaten this ideology. Or perhaps it is that these call to arms against possible corrupt regimes have been repeated over and over for thousands of years; that we as humans understand that there could be something better in the face of hardship, and continually strive for it.

In any case, this question plagues all of us: How healthy is American democracy? Do elements of corruption or despotism really exist in the United States government?

There are a frightening number of issues and complexities involved in a question like this. There are also just as many approaches to answering a question like this, be it rigorous empirical testing, pointed historical narrative, or analytic philosophical inquiry. This paper will be reviving the classical criticisms found in the political theory of Plato, Aristotle, and Thucydides and bringing these criticisms to bear on the problems of contemporary American democracy. These philosophers 
are perhaps the most famous critics of democracy, and understanding these criticisms can bring insight into the problems and events of the contemporary. Conveniently, the beginning of democratic criticism is also the beginning of political philosophy, which is considered the beginning of the academic field of political science. These philosophers are known, Plato especially, as the beginnings of political philosophy. As Alfred Whitehead said famously in his work Process and Reality, "The safest general characterization of the European philosophical tradition is that is consists of a series of footnotes to Plato." ${ }^{11}$ The Stanford Encyclopedia of Philosophy has it, "Political philosophy as a genre was invented in this period by Plato and reinvented by Aristotle..."2 Plato is focused on especially, but Aristotle and Thucydides also have an important part to play, in what can be considered the emergence of political interpretation of thought.

It does seem strange to focus upon something as abstract as classical political theory when trying to understand the very real problems of contemporary democracy. Yet theory, and the models of reality that it provides, is how we aim to understand the complexities of the world. Plato, Aristotle and Thucydides give understanding to the problems that plague democratic regimes and within it one can glean truth. There is clarity to be found in relating theory to contemporary reality, and a striking and real applicability of the theories of these philosophers. They are famous for a reason. This reason is that they discussed problems that occurred then, which are problems that are still occurring now. Thus we can surmise that their theoretical answers to political and philosophical quandaries can be of use to us. We can grasp an understanding of the problems of modern day democracy and why certain events are taking place. That is the purpose of this paper.

\footnotetext{
${ }^{1}$ Alfred North Whitehead, Process and Reality, (New York: Free Press, 1979), 39

2 Lane, Melissa, "Ancient Political Philosophy", The Stanford Encyclopedia of Philosophy (Fall 2011 Edition), Edward N. Zalta (ed.), <http://plato.stanford.edu/archives/fall2011/entries/ancientpolitical/>
} 
Plato lived from 428/427 - 348/347 B.C., Aristotle lived 384 - 322 B.C., and Thucydides lived from 460 to 400 B.C. They lived, thought and wrote in the time period surrounding the first significant rise of democratic states and the evolution of one of the most famous - Athens. They lived through the first democratic experiment and had a first look at the circumstances and motivations involved in the rise, fall, power struggles and inherent conflicts involved in such an undertaking as "rule by the people." In addition, each of these philosophers suffered at the hands of democratic citizens. Plato lost his beloved mentor, Socrates, at the hands of the democratic Athenian government. Aristotle not only grew up with anti-democratic sentiments in Plato's Academy, but was threatened with the same end as Socrates on account of a poem he had written years before honoring a friend of his. ${ }^{3}$ Thucydides himself was raised in a household of pro-Oligarchic democratic critics, and was exiled from Athens because of a supposed military failure. ${ }^{4}$ Perhaps this is why they have become such famous critics of democracy. Yet whether they were vengeful or not, the accuracy of their theories is not something to take lightly.

The ability of contemporary scholars to apply 2500 -year-old theories to modern regimes is due to the fact that these authors wrote about human nature and how people act under certain conditions. Considering that democracy is a regime built on the idea of all individuals being involved in state affairs, the government then being a reflection of the citizenry, this would seem to imply their theories are more critical and useful here than to other regime types. As will soon be seen, the main crux of these philosophers' argument is that people are inherently flawed and the best government is one with the power in the hands of the virtuous. Otherwise, regimes are extremely susceptible to tyranny and despotism. Their main issue with democracy stems from the fact that it has no institutions in place to make sure that the virtuous are in power, or protections against those who would seek to use the regime for their own purposes. While democracy is heavily criticized, it comes from a deep distrust of people and their actions.

\footnotetext{
${ }^{3}$ Aristotle, Politics, trans. Carnes Lord (London: 1984), 6

${ }^{4}$ Malcolm F. McGregor, "The Politics of the Historian Thucydides," Phoenix 10 (1956): 95
} 
In the tradition of Socrates - Plato's mentor - the theories of both Plato and Aristotle are laden with the concepts of morality and how one's life should be lived. As this paper will soon show, most of the theories of Plato and Aristotle come from a moral basis of either the make-up of people, or how things should be. Thucydides, on the other hand, comes from more of a historical, fact-driven concept of political realities and the issues involved. However, events are not all of what there is to Thucydides, as this paper will soon discuss.

In writing this paper, it will prove that the classical political theories of Plato, Aristotle, and Thucydides are still relevant and applicable to current democracies and people. In fact, their applicability may be all the more crucial today with all of the current contestation and concern surrounding democracy. In order to understand and prepare for possible future problems, one must first understand the past and the lessons that it supplies. In this case, it may be best to turn back to democracy in its first forms, when the ideal of rule by the people was first blossoming, and the critics that soon followed. The purpose of this paper is not to contest these philosophers' theories as right or wrong, nor to label democracy as a bad form of government. The purpose of this paper is to explore the ways in which their critiques of democracy continues to shed light on contemporary challenges of democracy. Furthermore, this paper will show that the usefulness of their theories comes from their understanding of the destructive aspects of human nature. In conclusion, this paper will prove that these authors' apparent distaste for democracy is a result of the very few safeguards that democracy has against negative aspects of human nature.

\section{PLATO}

First, let us turn to Plato. It seems that the best way to go about understanding his theories in relation to democracy is to first understand his perceptions on different types of constitutions (otherwise known as regime types or states), and what he considers to be the ideal society. This section on Plato will 
begin by describing how Plato describes his ideal state and different constitutions, then turn to his assessment on the causes for these constitutions coming about, and end with his perceived effects and consequences of these constitutions. This same approach - covering the description, causes, and consequences of democracy as seen by the philosopher- will be followed for the next two as well.

Before delving into this, I think it is important to make a quick note about Platonic interpretation. The interpretation of Plato's works has a long history of complex discussion and contention because the dialogue format of his works creates various ways to approach and take meaning from his words. Scholars of Plato throughout the ages have taken various positions on how to interpret and read Plato's works. The basic contention in interpreting Plato is addressed in J. Angelo Corlett's article "Interpreting Plato's Dialogues," where Corlett puts forth two different methods to decipher Plato: the Theoretical Interpretation and the Socratic Interpretation. Corlett describes the Theoretical Interpretation as believing that "Plato's writings ought to be taken as communicating the theories, doctrines, or beliefs of Plato himself,"5 and describes the Socratic Interpretation as assuming "that there is no specific view or way that the dialogues are to be read, except that they are to be taken as philosophical discussions engaging the readers in philosophical dialectic regarding various subjects." ${ }^{6}$ Corlett comes to the conclusion that the Socratic method seems the most accurate, because after debating the strengths and flaws of each method he finds several flaws in the Theoretical Interpretation as well as being concerned with it's lack of "rational support."7 While Socratic Interpretation seems to endanger a scholar to his or her own subjectivity, Corlett states that this method of interpretation really is dogmatic, and is simply freeing up the ability to read more dynamically and discover more intricacies within the texts. ${ }^{8}$

\footnotetext{
5 J. Angelo Corlett, “Interpreting Plato's Dialogues," The Classical Quarterly 47 (1997), pp. 423

${ }^{6}$ Corlett, “Interpreting Plato's Dialogues," pp. 434

7 Corlett, "Interpreting Plato's Dialogues," pp. 425

8 Corlett, “Interpreting Plato's Dialogues,” pp. 435
} 
It does not seem likely that Plato would have chosen the dialogue form without intention, so Corlett has a valid point in being concerned that interpreting direct doctrines from the text is too stringent. Plato could have written treatises if he wanted to simply inform, as Aristotle did. I think that as a pupil of Socrates he, for obvious reasons, believed in the Socratic method; that it was more important that someone was able to think than teaching someone what to think. However, I also suspect that there are gems of Platonic knowledge to be found for those who think deeply and analytically enough about it. There are layers upon layers of meanings that can be inferred from Plato's dialogues, as the enormous body of literature written on Plato proves. However, this paper has neither the space nor the time to complete such a task, nor is that the end goal. For the purposes of this paper, some liberties are going to be taken on the complexities of Plato's works.

\section{Description}

Plato's ideal state, as well as his criticism of other constitutions, is developed in his dialogue The Republic. The Republic is arguably the most developed of his dialogues upon a range of political and moral considerations. At the very least, it is the most applicable for the purposes of this paper. This paper will also look at a few of Plato's other dialogues that address certain moral considerations, as morality and virtue has been already mentioned as extremely important to the development of Plato's theories. But none are as developed, at least politically, as The Republic.

Plato addresses five different kinds of regimes in The Republic: Timarchy, Oligarchy, Democracy, Tyranny, and his ideal state, which can be put into the realm of an Aristocracy. With each regime that Plato describes, he also contrasts with the behavior or type of person that he supposes would live in each constitution, giving an overall mental and psychological picture of the society as a whole. Within this context, Plato describes each state as being driven by the nature and character of its citizens, who Plato thinks ultimately drive the state in particular directions. The Republic starts by trying to define what "Justice" is and ends up becoming a meticulous creation of Plato's ideal state. In this, Plato addresses many moral considerations of politics and government. 
Plato believed his ideal state should be a community of one; an interlocking society where everyone relied on each other for support and needs. Everyone had a particular part to play within society (their particular talent they are innately good at), for the betterment of the whole. He organized his ideal state so that the rulers, which he calls "Guardians," did not actually have wealth or possessions themselves, their needs provided for by the producers (the bronze) in payment for their protection, to create unity, and so the Guardians could dedicate their lives to philosophy, virtue, and ruling justly. ${ }^{9}$ In fact, the Guardians were forbidden to own property or have wealth; this was so that they would not be tempted to the path of personal profit and gain, a common theme throughout Plato's Republic. ${ }^{10}$ Plato designated that his ideal state would have meticulous and in-depth education system for different types of people. He also had community child-rearing and reproductive organization; he believed in disbanding the family unit, rearing children as a collective, and having no marriages. This way, he reasoned, it diverts family loyalties, affections, and interests to the service of the community. ${ }^{11}$ While harsh, in some regards this is a crude form of social mobility: with parentage unknown and children raised together, a child could develop with whatever talents he or she had the aptitude for without parentage creating a pre-determination.

Timarchy, which is what Plato begins with, is like an aristocracy. But instead of the most virtuous and wise being the rulers of the state, Plato conceptualizes this constitution as having inferior people in the position of ruling. Instead of intelligence in the seat of power, Plato writes that the simpler and more war-minded individuals will rule. Plato attributes this to the corruption of money causing moral values to have lesser importance within the soul because of lack of reason; private property and personal property becomes the main motivator. Instead of virtue, ambition and competitiveness is what is valued. ${ }^{12}$

\footnotetext{
9 Plato, The Republic, trans. Desmond Lee (New York: Penguin Group, 1974) 184-185

10 Plato, The Republic, 183 - 187

11 Plato, The Republic, 236 - 237

12 Plato, The Republic, 359 - 364
} 
Plato addresses Oligarchy next. He describes Oligarchy "a society where it is wealth that counts...and in which political power is in the hands of the rich and the poor have no share of it."13 Plato writes that in this state, ownership of a minimum amount of property is required for the ability to take office or have a say in legislative affairs. Plato describes an Oligarchy as having a huge divide between the wealthy and the poor, who "are always plotting against each other."14 There is no virtue or education, and if there is, it is likely of bad quality. This is also where Plato starts to describe a "drone" individual; a useless, rich person who neither rules nor serves society in any way, only consuming goods and spending money. He writes, "some [have] no stings and some very formidable ones; and that the stingless type end their days as beggars, the stinging type as what we call criminals..."15

Plato then addresses Democracy. He describes it as rule by the many poor, with an abundance of liberty and freedom to do whatever one likes. Plato even writes "I dare say that democracy is the most attractive of all societies... [t] diversity of its characters...make it look very attractive. Indeed...perhaps most people would, for this reason, judge it to be the best form of society, like women and children when they see gaily coloured things." 16 Plato describes the excessive liberty in Democracy as turning to the extreme, and "you find that the mind of the citizens become so sensitive that the least vestige of restrain is resented as intolerable, till finally...in their determination to have no master they disregard all laws, written or unwritten."17 His biggest problem with democracy is that it is sorely lacking in moral excellence and good education. He writes, "the father [stands] in awe of his son, and the son neither respecting nor fearing his parents, in order to assert what he calls his independence....The teacher fears and panders to his pupils, who in turn despise their teachers and attendants; and the young as whole imitate their elders, argue with them and set themselves up against them, while their elders try to avoid

\footnotetext{
13 Plato, The Republic, 366

14 Plato, The Republic, 368

15 Plato, The Republic, 369

16 Plato, The Republic, 375

17 Plato, The Republic, 384
} 
the reputation of being disagreeable or strict by aping the young..."18 He continues with, "[w]e said that no one who had not exception gifts could grow into a good man unless he were brought up from childhood in a good environment and trained in good habits. Democracy with a grandiose gesture sweeps all this away and doesn't mind what the habits and background of its politicians are; provided they profess themselves the people's friends, they are duly honoured."19 Instead of understanding moral virtue and being able to resist bad appetites or desires, Plato describes democratic citizens as being swayed by whatever takes their fancy. They are easily subject to charming, smooth-taking people who wield rhetoric as their weapon, the citizens not having the good education to make logical choices for themselves. Plato concludes that Democracy is very susceptible to falling under the influence of bad leaders. ${ }^{20}$

Tyranny is the final state Plato addresses. The word itself is pretty selfexplanatory: a single ruler who wields all the power. Plato describes the tyrant as enforcing high taxation to keep everyone in poverty, hiring bodyguards because the tyrant can't trust the citizens, handing over to enemies anyone who rises up against him, and constantly provoking war. He wields high powers of rhetoric and charm, but maintains a private army that he uses to terrify the citizens into constant submission. Plato describes the character of his man as essentially criminal, keeping the company of criminal types as well. ${ }^{21}$

Next this paper will turn to Plato's reasoning for the causes and conditions of these states coming into being.

\section{Causes and Conditions}

The causes of Timarchy, Oligarchy, Democracy and Tyranny coming about are fairly straightforward. As one may have noticed by reading the above descriptions of different constitutions, they all seem to have connections; in all actuality, Plato describes these constitutions in The Republic as different steps of

\footnotetext{
18 Plato, The Republic, 383

19 Plato, The Republic, 376

20 Plato, The Republic, 379 - 381

21 Plato, The Republic, 382 - 398
} 
degradation from his ideal state. He saw his ideal state degrading into Timarchy, then Oligarchy, Democracy, and finally Tyranny. He only addresses these other constitutions as "Imperfect Societies." 22 In looking through the lens of the Socratic Method, it is reasonable to think that Plato was looking at these constitutions as a way to instill moral teachings. For now this paper will look at the face-value of Plato's writings on these constitutions, keeping in mind the possible moral undertones involved.

At the heart of Plato's explanations of different regime-types is his understanding of human nature in its various forms. Plato's ideal state relies heavily upon his theories surrounding the moral make-up of people. He believes all individuals have a particular talent that they are innately good at, and it is only through specializing in their particular talent that the most good can be done for the community as a whole. He writes, “...no two of us are born exactly alike. We have different natural aptitudes, which fit us for different jobs." ${ }^{23}$ He describes people as having three different parts within themselves: appetite, spirit, and reason. ${ }^{24} \mathrm{He}$ also describes these parts as need to have a particular order within each person; specifically, that appetite and spirit are subject to reason. He believes that only through reason can a person be wise and virtuous, having the self-discipline and rationality to suppress unhealthy appetites or desires, unruly emotions, and have mastery over oneself. ${ }^{25}$ Plato also claims that these different parts develop to a different degree within each different type of character, making them prone to certain desires and lifestyles. He relates the part of appetite to the desire for gain, the part of spirit to the motivation for success, and the part of reason to the motivation for knowledge. He writes, "[t]hat is why we divide men into three basic types, according to whether their motive is knowledge, success or gain."26 Plato begins to call these three classifications of men as Bronze, Silver, and Gold. Those motivated by gain - otherwise known as money and possessions - are called the

\footnotetext{
22 Plato, The Republic, 356

23 Plato, The Republic, 118

24 Plato, The Republic, 206 - 217

25 Plato, The Republic, 218 - 221

26 Plato, The Republic, 405
} 
Bronze; those motivated by success - or honor - are called Silver; and those motivated by knowledge are called Gold. As is probably obvious here, Plato establishes a hierarchy of kinds of people. Plato again emphasizes that appetite and spirit being subject to reason. If one has mastery over oneself, he argues, then reason can lead to virtue and wisdom. Relating this to people, he believes this is the way to harmony and makes it one of his requirements within his state. ${ }^{27}$

Plato believed that those who took political office had to have the proper qualifications and abilities, "for political authority is the most difficult and the most important." 28 He writes in his dialogue Statesman, where he defines and describes Political Science and Political Philosophy, that, "No other art or science will have a prior or better right than in the royal science to care for human society and to rule over men in general." ${ }^{29}$ He considered political knowledge to be the royal science and supreme art, and only those who thoroughly understood it could be just and wise rulers. Those he defined as "gold," or those motivated by knowledge, he believed were the only ones with the ability - or even desire - to understand political knowledge and virtue. Also, since this desire for truth and wisdom forms the majority of the philosophers' souls, he believed these individuals will primarily strive for truth and wisdom. Furthermore, since Plato believed this portion of their souls is also rational, he believed their rule would be just; assuring that the city they ruled was also just. Plato deemed these “Gold” as Guardians, or Philosopher Kings, because he believed the perfect ruler was a combination between a king and a philosopher. Robert Dahl, in his book Democracy and Its Critics, articulates Plato's argument by saying, "[t]he guardians must not only, like true philosophers, discern more clearly than all others what is best for the community, but they must also be wholly dedicated to achieving that end and therefore must possess no interest of their own inconsistent with the good of the polis. Thus they would unite the truth seeking and knowledge of the true philosopher with the dedication of a true king or true aristocracy - if such could exist - to the good of the community over which they

\footnotetext{
27 Plato, The Republic, 202 - 203

28 Plato, The Republic, 368

${ }^{29}$ Statesman, in Dialogues v. 3, Jowett trans., para 276c, p. 488
} 
rule." 30 Plato relates the Philosopher-Kings as "watchdogs" in the community, needing to be kind to the citizens and aggressive to strangers, and being both gentle in character and full in spirit. ${ }^{31}$

Plato did not, however, believe that the Guardians would develop without guidance. Dahl summarizes Plato's thoughts by saying, “[j]ust as all men are not equal excellence as physicians or pilots, so some are superior in their knowledge of the political art. And just as excellence as a physician or a pilot requires training, so too men and women must be carefully selected and rigorously trained in order to achieve excellence in the art and science of politics." ${ }^{2}$ In believing that people were not naturally good, Plato believed that goodness and virtue must be taught and promoted within people. He describes those without education as "unintelligent philistine, with no use for reasoned discussion, and an animal addiction to settle everything by brute force. His life is one of clumsy ignorance, unrelieved by grace or beauty." ${ }^{33}$ In this regard Plato believed that these Guardians would only exist if they were trained and educated.

In his ideal state, Plato creates a thorough and meticulous education system focused around the idea of creating, promoting, and provoking a sound mind, virtue, and goodness within an individual. He starts with children, concerned about their susceptibility to bad impressions made upon them, not wanting them to grow up with in a bad environment with immoral tales. ${ }^{34}$ "For rhythm and harmony penetrate deeply into the mind and take a most powerful hold on it, and, if education is good, bring and impart grace and beauty, and if it is bad, the reverse....the proper training we propose to give will make a man quick to perceive the short-comings of works of art or nature...anything ugly he will rightly condemn and dislike, even when he is still young and cannot understand the reason for so doing, while when reason comes he will recognize and welcome her as a familiar

\footnotetext{
30 Robert Dahl, Democracy and its Critics, 53

31 Plato, The Republic, 126

32 Robert Dahl Democracy and its Critics pg. 53

33 Plato, The Republic, 176

34 Plato, The Republic, 131 - 149
} 
friends because of his upbringing." 35 In case that one is missed, Plato is declaring reason as the ultimate beauty and harmony. In his curriculum he details reading, writing, physical education, poetry and literary education, and music education, distinguishing the good from the bad and outlining what morals and ideals need to be taught. ${ }^{36} \mathrm{He}$ details the Guardians as the overseers of this first education, stating, "there [must] always [be] someone like this in charge of education in our state, if its constitution is to be preserved." 37

Yet this was just the education for everyone in general, in order to create beauty and harmony for his state as a whole. As we know, Plato believed that not all people desired - or even were necessarily capable of - the deep thought and wisdom that were necessary for his rulers. He describes further education needed for his Guardians, the main stress in his curriculum being the training for the ability of thought. ${ }^{38}$ The education written about above, Plato envisions happening until 18; from 18 - 20 he envisions two years of physical training and military service. Between the ages of twenty and thirty selected candidates are put through the mathematical disciplines of arithmetic, plane and solid geometry, astronomy, and harmonics. ${ }^{39}$ From there, after more selection, there will be five years of philosophic education, followed by fifteen years' practical experience in subordinate offices in which they will have to stand up to temptations of all kinds. ${ }^{40}$ Plato writes that all of these selection stages are tests in which only the best in aptitude for learning and education are really going to pass; this is how the Gold are separated from the rest. After all these tests, at fifty years of age, they are finally ready to be Philosopher Kings. Plato even makes sure to emphasize that women will be philosopher kings as well, for some of them will have the natural Gold capacities. ${ }^{41}$ Then, “...the rest of their lives they will spend the bulk of their time in philosophy, but when their turn

\footnotetext{
35 Plato, The Republic, 163

36 Plato, The Republic, 129 - 176

37 Plato, The Republic, 176

38 Plato, The Republic, 326 - 331

39 Plato, The Republic, 326; 347

40 Plato, The Republic, 353-354

41 Plato, The Republic, 354
} 
comes they will, in rotation, turn to the weary business of politics, and, for the sake of society, do their duty as Rules, not for the honour they get by it but as a matter of necessity. And so, when they have brought up successors like themselves to take their place as Guardians..." ${ }^{42}$ Notice that Plato describes the Philosopher Kings as not wanting to rule. He writes, "The truth is that if you want a well-governed state to be possible, you must find for your future rulers some way of life they like better than government....If you get, in public affairs, men whose life is impoverished and destitute of personal satisfactions, but who hope to snatch some compensation for their own inadequacy from a political career, there can never be good government."43 Altruism, wisdom, virtue and rationality are all characteristics that Plato believes can be instilled and taught to his Gold for the good of his state; but he also believed they also must not like ruling, for a love of ruling equals someone who would not want to give up power.

Plato also addresses the roles of Silver and Bronze people in his ideal state. The Silver, or those he believes were primarily made up of the motivation for honor with spirit and passion as their primary force, he also considered a kind of Guardian. In fact, Gold and Silver are not defined as separate until his Part IV, where he discusses his concern of the best of the best specifically governing all. ${ }^{44}$ His concern with the Silver lies in the fact that with desire for honor and passion being most of the make-up of their souls, they could easily become "ruled" by this and use their superior strength and behave "more like savage tyrants than partners and friends." ${ }^{45}$ Being spirit, his philosophy dictated they needed to be ruled by reason or the Gold - and again returns to the need of proper education. ${ }^{46}$ Plato regarded the Silver as the warriors or soldiers of the state, deeming their responsibility to protect the state through military means and to execute the orders of the Gold. ${ }^{47}$

\footnotetext{
42 Plato, The Republic, 354

43 Plato, The Republic, 325

${ }^{44}$ Plato, The Republic, 178 - 180

45 Plato, The Republic, 183

46 Plato, The Republic, 183

47 Plato, The Republic, 177
} 
Plato believed that most people are Bronze in character, and make up the citizenship that needed both protection and governance. ${ }^{48}$ Because the Bronze are appetite, motivated by gain and possessions, Plato believed that without something to hold them in check the Bronze would become consumed by the desire for more and more gain. Plato's belief in appetite being ruled by reason transfers over to his argument that the Bronze had to be ruled by the Gold. In speaking in both the literal and figurative, "... [spirit and reason] must be put in charge of appetite, which forms the greater part of each man's make-up and is naturally insatiable. They must prevent it taking its fill of the so-called physical pleasures, for otherwise it will get too large and strong to mind its own business and will try to subject and control the other elements, which it has no right to do, and so wreck the life of all of them."49 Thus Plato establishes his hierarchy in both individuals and citizens within a state.

With the conditions of his ideal state illustrated, there can be further description of the degradation of his ideal state into the other "Imperfect" forms. Plato theorized his ideal state would first degrade into a Timarchy because more bronze or silver children would be born rather than gold, causing the 'best' to slowly decline in quality over time. 'Unworthy' individuals would be put into positions of leadership, they would undervalue the education training of the mind and body, with the result that the next generation would be worse educated. ${ }^{50}$ Degradation in education, along with a mix of Bronze entering the Gold and Silver bloodlines, causes the pull towards private property and personal profit, as well as warlike behavior, to rise and take over the rulers. As mentioned in the description, ambition and competitiveness would soon be valued over virtue, causing simpler and more war minded individuals in the position of leadership.

In describing the degradation from Timarchy to Oligarchy, an "accumulation of wealth in private hands is what destroys timarchy. The men find ways to become extravagant, and for this reason pervert the law and disobey it, and the women

\footnotetext{
48 Plato, The Republic, 122

49 Plato, The Republic, 219

50 Plato, The Republic, 360 - 361
} 
follow their example." ${ }^{1}$ Thus, "there is a transition from the ambitious, competitive type of men to the money-loving businessman, honour and admiration and office are reserved for the rich, and the poor are despised." ${ }^{52} \mathrm{He}$ describes the Oligarchic society as a society of greed, where "[m] ost people are beggars except the ruling class." ${ }^{53}$ Plato also writes that the love of money and self-discipline cannot coexist in the citizens of any society, and wastefulness within an Oligarchy causes "men born for better things" to be reduced to poverty. ${ }^{54}$ Plato is very critical of the corruptive power of money causing immorality to run rampant through a state.

In writing of the transition from Oligarchy to Democracy, poverty and strife is the main driving force. He writes about those in poverty: "[s]ome of them are in debt, some disfranchised, some both, and they settle down...with hatred in their hearts, to plot against those who have deprived them of their property and against the rest of society, and to long for revolution." 55 Meanwhile the rich "don't appear to notice them," and "their young men live in luxury and idleness, physical and mental, become idle, and lose their ability to resist pain or pleasure."56 Specifically, the rich have no physical prowess because of their idleness. Democracy arises from the revolution that follows, for "democracy originates when the poor win, kill or exile their opponents, and give the rest equal civil rights and opportunities in office, appointments to office being as a rule by lot." 57 For the poor, with hated in their hearts, who are better equipped both physically and in numbers, gain control of ruling.

Democracy, as already detailed above, Plato describes as a very rich state culturally. Diverse characters and liberty abounds. However, Plato cautions that an extreme will result in the opposite extreme; that an excess of liberty will result in an excess of subjugation. Plato describes the democratic type character as not having

\footnotetext{
51 Plato, The Republic, 367

52 Plato, The Republic, 367

53 Plato, The Republic, 369

54 Plato, The Republic, 373

55 Plato, The Republic, 373

56 Plato, The Republic, 374

57 Plato, The Republic, 375
} 
grown up with decent practices or self-discipline, and is easily swayed by the "drone" type individual who is prone to the abundance of unnecessary pleasures. ${ }^{58}$ Indeed, "the young man's mind is devoid of sound knowledge and practices and true principles, the most effective safeguards the mind of man can be blessed with." 59 And falling in with bad associations, "[t]he vacant citadel in the young man's mind is filled instead by an invasion of pretentious fallacies and opinions." ${ }^{\prime 60} \mathrm{He}$ writes that this individual would live by only indulging in the pleasures of the moment, unconcerned with bigger issues or the difference between right and wrong. ${ }^{61}$ In this, Plato describes democratic citizens as being very easily swayed by bad opinions, and coming under the subjugation of bad leaders. ${ }^{62}$ Plato uses his "drone" character all throughout his explanation of the fall of democracy to tyranny; the "energetic leaders" being drones with stings, and the "inert mass of followers" to drone without stings. Plato creates three groups: the energetic group that does the talking and acting, the steadiest characters that are that the most successful at making money, and the third group, which is the mass of people who earn their living and take little interest in politics. ${ }^{63}$ Plato describes a society where the leaders rob the rich, keep as much as they can for themselves, and distribute the rest to the people. This perpetuates the war that existed within an Oligarchic society: when the rich stand up and attempt to defend themselves, "[ $t]$ hey are accused by their rivals of plotting against the people and being reactionaries and oligarchs, even though in fact they may have no revolutionary intentions." 64 And in this struggle, Plato describes the people as putting forward a single popular leader to which they nurse into greatness.

This popular leader is very important, for this Plato describes as the transition from Democracy to Tyranny. He describes the "mob" as doing anything

\footnotetext{
58 Plato, The Republic, 377 - 379

59 Plato, The Republic, 379

60 Plato, The Republic, 379

61 Plato, The Republic, 381

62 Plato, The Republic, 383

63 Plato, The Republic, 385 - 386

64 Plato, The Republic, 386
} 
the popular leader tells them to do, where the popular leader will bring "the usual unjust charges against [the oligarch], take[ing] him to court and murder[ing] him, thus destroying a human life, and getting an unholy taste of the blood of his fellows. Exiles, executions, hints of cancellation of debts and redistribution of land follow, till their instigator in inevitably and fatally bound either to be destroyed by his enemies, or to change from man to wolf and make himself tyrant....It is he who leads the class war against the owners of property." 65 From this, Plato describes the tyrant as demanding a personal bodyguard to preserve "their champion" which the people grant, fearing for his life.66 Plato writes that the tyrant, once he has disposed of enemies, will continue to stir up war in order that the people may continue to need a leader. From here, Plato describes the tyrant and slowly accumulating power of the state through smiles, kind words, big promises, and distribution of property. Those who stand up to him within his state he will quietly hand over to his enemies, and he will continue to grow his personal army by hiring those who are not citizens of his state (and thus he cannot explicitly trust). By the time the citizens of the state realize what a character they have "bred and groomed for greatness," they will have "exchanged their excessive and untimely freedom for the harshest and bitterest of servitudes, where the slave is master."67

And that is how Plato describes the degradation from his ideal state, to Timarchy, to Oligarchy, to Democracy, to Tyranny. Each transition has worse consequences. Through the corrupting influence of wealth, virtue is discarded for ambition and competitiveness and wars will plague the state. It worsens even further when the warrior is replaced the businessman, causing extreme conflict within the state and the beginnings of civil war. With the culmination of a revolution where extreme liberty arises, ignorance and excess with lend itself to the extreme danger of tyrannical rule. When this tyrannical rule rises, there will be an explosion of exiles, executions, class warfare against property owners, redistribution of wealth, warfare with other nations, and more importantly for Plato, a complete lack

\footnotetext{
65 Plato, The Republic, 387

66 Plato, The Republic, 387

67 Plato, The Republic, 391
} 
of virtue or higher purpose. Crime will rule the state. Next, we will turn to Plato's conceptualization of the effects of these different constitutions and the consequences of them.

\section{Effects and Lessons}

It might seem redundant to explain Plato's perceived consequences of these constitutions - it would appear that Plato's belief in the consequences of all constitutions but his ideal is they are all imperfect and inevitably leading to tyranny. This is not only just in regard to tyranny of an individual, but tyranny of the majority as well. Plato's dialogue Apology is generally attributed as his work addressing tyranny of the majority; in it, Socrates defends himself against the Athenian court and is ultimately condemned to death. ${ }^{68}$ The crucial moment within this dialogue is when Socrates states that no one would be able to stand up against the popular majority, that they ultimately have all the power. ${ }^{69}$ Individuals can be drowned out and condemned, even if the individual is right, because of the nature of people in groups sticking together in a "mob." Plato is especially critical of "mob-mentality" and the ability of groups to trample what is "truth" and "wisdom."

While this is all very depressing and pessimistic, now is the time to step back from direct interpretation and take a look at the moral and philosophical knowledge he could be imparting. Using the earlier mentioned Socratic Interpretation, it can be found that Plato is relating lessons to be learned. There are two very important understandings to take from Plato's degradation of constitutions. The two main things that he describes as beginning the corruption of his ideal state are the decline in the quality of education and an increase in a concern for private property or personal profit. These two themes - the maintaining of quality education and the protection against the excessive zeal of personal profit - provide two main lessons for the contemporary that arise from Plato. In addition, a third lesson, the guarding against the persuasive power of rhetoric, is related to these two lessons because

\footnotetext{
68 Plato, Apology in The Last Days of Socrates, trans. Christopher Rowe (New York: Penguin Group, 2010) 69 Plato, Apology, 50
} 
Plato believed that those who were well educated and had a decent sense of the public good would be able to see through this manipulation. It is important to understand the human nature implications of this; the belief that when someone steps down from a life of wisdom and virtue, education declines and concern for money starts to take over, then human nature's darker side takes over.

In addition to the subject of rhetoric, Plato devotes an entire dialogue to the subject of rhetoric, called Gorgias, after the famous rhetorician. Plato had a great distrust of rhetoric and rhetoricians, believing that the common (bronze, or uneducated) person would almost always be swayed by fancy speech instead of believing the truth and the knowledgeable. In Gorgias, Plato debates the role of rhetoric with the famous rhetorician Gorgias. Plato defines rhetoric as "an agent of the kind of persuasion which is designed to produce conviction, but not to educate people, about matters of right and wrong."70 Gorgias professes rhetoric as an instrument of power politics and having the ability to persuade the uneducated. ${ }^{71}$ The rest of Gorgias is devoted to debating moral issues; two of the characters within the dialogue (Polus and Callicles) approve of rhetoric because of it's ability to exercise power over other people and indulge one's own whims, while Socrates believes that doing wrong to others (which he believes rhetoricians will ultimately do, because they can) is immoral and will ultimately lead to unhappiness. ${ }^{72}$ It is also important to note that Plato believed his mentor, Socrates, was put to death because of talented rhetoricians. This probably caused Plato to have a particular vendetta against rhetoricians - as many have argued, considering the harshness of this dialogue - but does not make Plato's arguments of rhetoric any less important to consider. As displayed in his described progression from democracy and tyranny, the effects of rhetoric can have devastating consequences. Plato believed that most citizens within most constitutions would ultimately fall under the influence of rhetoric and be lost to power plays. If there were those who didn't fall under this

\footnotetext{
70 Plato, Gorgias, ed. Robin Waterfield. (New York: Oxford University Press, 1994), 17, 455a

71 Plato, Gorgias Introduction xii

72 Plato, Gorgias Introduction xiii - xiv
} 
influence, he believed they would be discredited or falsified, which will be explained here below.

Plato's concern for moral and intellectual education can be related to another one of his theories. What is often deemed his Theory of Universals, his Simile of The Cave, or his Cave Allegory, is also described in Plato's Republic. This is a story that Plato tells about, well, people in a cave. Plato describes these people as chained to a wall. Behind the wall, there is a fire with shadow puppets casing pictures upon the wall in front of the chained people. The shadows are the only reality that the people chained to the wall know. Plato - Socrates - then tells of a tale where one of these people escapes out of the cave, and finds there is a whole world of light outside, with real things - real trees, real sky, real grass, unlike the fake shadows cast on the wall. The final step of this story is of this now freed person - who has often been described as Socrates himself - gathering his courage returning to the dark cave to try to rescue the others. ${ }^{73}$ Plato relates this "going to the upper world" and then the returning to the "prisoners in the cave" as the path of philosophic knowledge; a philosopher coming to understand and truth about reality and real things and then undertaking the task of implementing these truths to the human world in order to create the best good. ${ }^{74}$ Plato describes this path as one his Guardians must undertake. ${ }^{75}$ However, Plato also cautions that those who have seen the "real light" of the upper world will be blinded upon returning to the dark, their "eyes" unaccustomed to the darkness, and might "blunder and make a fool of himself, if, while still blinded and unaccustomed to the surrounding darkness, he's forcibly put on trial in the law-courts or elsewhere about the shadows of justice or the figures of which they are shadows, and made to dispute about the notions of them held by men who have never seen justice itself." 76 It seems as though Plato carries both an excuse and distain in this. He seems to be excusing philosophers from not being able to explain his "upper world" of truth to those who have not seen it (at least at first),

\footnotetext{
73 Plato, The Republic, 317 - 325

74 Plato, The Republic, 323 - 325

75 Plato, The Republic, 325

76 Plato, The Republic, 321
} 
while at the same time being somewhat antagonistic towards those who try to understand such things as justice when he feels they are "shadow people" who either cannot or have not understood such things. He believes those who uneducated are perpetrators of injustice and ignorance.

All of this relates to the effects of constitutions because Plato seems to be saying that if a specific constitution exists without requiring wisdom and ultimate truth, then the only reality that people will know will be false or of the power plays of those who are good manipulators. Plato's view on the importance of education seems pretty clear. It is crucial for citizens in order to tell the difference between right and wrong and lead a life of virtue, as well as protect the state from those who would corrupt the state for personal gain. More literally, only Plato's ideal state would be living in a world that attempts to exemplify truth and wisdom. Also, because he believes that true happiness only comes from being virtuous, all of the citizens of these "inferior" constitutions would lead unhappy lives.

Plato's main focuses are virtue, truth, education, reality, the corrupting influence of private property and personal gain, and rhetoric. He has a very pessimistic view on constitutions and the people that are involved. As this paper turns to Aristotle, we will find he has similar conceptions about the world and people, but constructs it in a completely different way. Let us turn to him next.

\section{ARISTOTLE}

In contrast to Plato, Aristotle wrote treatises instead of dialogues. He also is known for how systematic and "scientific" his writings are. This makes him much easier to draw literal meaning from. Aristotle's primary works dealing with politics and ethics are, aptly named, Politics and Nicomachean Ethics. Politics is a work of political philosophy, literally meaning "the things concerning the polis." Nicomachean Ethics deals in the ethics of how one's life should be lived, continuing in Plato and Socrates' footsteps. Both of these works are concerned with people being (or becoming) good; Ethics is concerned with individuals, while Politics comes 
from the perspective of lawgiver in implementing the best political association to facilitate goodness.

Aristotle is not only concerned with ideal constitutions and government systems, but also investigates second-best or even inferior political systems. This is because, while the ideal is most certainly strived for, inferior constitutions may be the closest approximations of what he conceives of as "political justice" that a lawgiver can attain under certain circumstances. In order to understand Aristotle, this paper will first turn to his descriptions of different constitutions and ideal states, the causes of these constitutions coming about and their conditions, and finally the effects and consequences of these constitutions.

\section{Description}

The exploration of the different kinds of political systems and political justice plays out in Aristotle's Politics. Politics starts off by defining a polis, or city, as a political association and community. He states that all associations are created with the aim of achieving some good, but that political associations are sovereign because it incorporates all other forms of associations and aims for the highest good. ${ }^{77}$ For Aristotle, the aim of politics is happiness: the overall good and happiness of the community, which was the supreme good..$^{78}$ And not happiness as in pleasure or happiness as in honor, but Aristotle's supreme happiness: a life of philosophy and contemplation. ${ }^{79}$ Happiness for the individual and happiness for the state he perceived as the same. ${ }^{80}$ His ideal way of life for both individual and city is that of noble actions and virtue, and noble cities could only come by way of noble citizens. ${ }^{81}$

Aristotle places a great emphasis on constitutions and definitions, believing that while the citizens are the material that makes up a city, the constitution is the form. He says that every city is made of quality and quantity; quality being freedom, wealth, education and good birth, while quantity is the majority of people within a

\footnotetext{
77 Aristotle, Politics, trans. Carnes Lord (London: 1984), Bk. 1 Ch. 1 (1)

78 Aristotle, Nichomachean Ethics, trans. Roger Crisp (Cambridge: Cambridge, 2000), 5

${ }^{79}$ Aristotle, Nichomachean Ethics, 7 1096a

${ }^{80}$ Aristotle, Politics, Bk. 7 Ch. 2 (1)

${ }^{81}$ Aristotle, Politics, Bk. 7 Ch. 1 (11) - (13)
} 
state ${ }^{82}$ Aristotle articulates that since there are a number of parts to a city, which all share in the regime in different ways, then there must be a number of regimes differing from one another, since these parts differ from one another ${ }^{83}$ He defines a regime as an arrangement of offices that distribute power on the basis of whatever the regime views as equality. ${ }^{84}$ He concludes this somewhat confusing thought train by saying that there are as many regimes as there are arrangements of both the majority and the parts of a regime. ${ }^{85}$

Aristotle broadly defines constitutions depending on how large the governing body was: a single person; a small, elite group; or the masses. Government by a single person was a kingship (or monarchy), by a small group is aristocracy, and by the masses is polity. ${ }^{86} \mathrm{He}$ does spend quite a lot of pages describing how there are many variations within each of these constitutions depending on the variations of the "parts" of a regime, but for simplicity's sake this paper will stick to the broad forms. The most important characteristic of all of these is that they rule for the community as a whole. Aristotle actually defines six kinds of government total; the three constitutions just mentioned, based on size, and their opposites when these constitutions are corrupt. The corruption of monarchy, when a kingship was solely directed in the interest of the ruler, he considered a tyranny. ${ }^{87}$ The corruption of aristocracy, directed towards the sole interest of the wealthy, he considered an oligarchy. ${ }^{88}$ And the corrupted polity, directed in the sole interest of the poor, Aristotle saw as a democracy. ${ }^{89}$ The main difference between corrupt and just states in Aristotle's mind is that in corrupt states, "none of them is with a view to the common gain." 90 Instead, interest is directed solely towards those who are in power.

\footnotetext{
82 Aristotle, Politics, Bk. 4 Ch. 12 (1)

83 Aristotle, Politics, Bk. 4 Ch. 3 (1) - (5)

${ }^{84}$ Aristotle, Politics, Bk. 4 Ch. 3 (5)

85 Aristotle, Politics, Bk. 4 Ch. 3 (6)

${ }^{86}$ Aristotle, Politics, Bk. 3 Ch. 7 (3)

${ }^{87}$ Aristotle, Politics, Bk. 3 Ch. 7 (5); Ch. 8 (2)

88 Aristotle, Politics, Bk. 3 Ch. 7 (5); Ch. 8 (2)

${ }^{89}$ Aristotle, Politics, Bk. 3 Ch. 7 (5); Ch. 8 (2)

${ }^{90}$ Aristotle, Politics, Bk. 3 Ch. 7 (5); Ch. 8 (2)
} 
Aristotle saw another defining feature of the difference between correct and corrupt constitutions as based on friendship. He saw three types of friendship; friendship based off of the benefit people get from each other (utility), attraction based off of looks or the like (pleasantness), or friendship based off of admiration of other's goodness and to help one another strive for goodness (virtue)..$^{91}$ Aristotle saw the final kind of friendship as both the only true and long-lasting kind of friendship, as well as the key element in a governing body. Aristotle saw the relationships between people, and the relationships within a household, as analogous to certain types of political constitutions. He writes, "particular kinds of friendship will correspond to particular kinds of community." 92 He saw the relationship of fathers to sons as monarchic, the relationship between a man and a woman as aristocratic, and the relationship between brothers as like a polity, or timarchic. ${ }^{93}$ Bad friendship on the parts of these relationships led to the bad forms of them. If no long-lasting friendship existed in the relationship between a ruler and the ruled, the political institution was corrupt. No or bad friendships led to tyranny, oligarchy, and democracy. ${ }^{94}$ Specifically, he saw a household with a weak person in charge, where anyone can do whatever he likes, as democratic. ${ }^{95}$

Aristotle ties Aristocracy and Polity together, saying they are often similar to each other and "hence we may speak of both as one."96 Aristotle writes that polities are generally a combination between the good attributes of oligarchy and democracy, or more accurately, a mixture between the well off and the poor. ${ }^{97} \mathrm{He}$ says that that it is "customary" to call polities that tend towards either democracy or oligarchy as aristocracies, because those that have the good education and birth needed for virtue tend to be well off. ${ }^{98}$ Aristocracies, on the other hand, Aristotle defines specifically as a combination of three elements: the poor, wealthy, and

\footnotetext{
91 Aristotle, Nichomachean Ethics, 146 - 147 1156a - 1156b

92 Aristotle, Nichomachean Ethics, 155

93 Aristotle, Nichomachean Ethics, 156 - 157 1160b - 1161a

94 Aristotle, Nichomachean Ethics, 155 - $1561160 \mathrm{~b}$

95 Aristotle, Nichomachean Ethics, 157 1161a

96 Aristotle, Politics, Bk. 4 Ch. 11 (2)

97 Aristotle, Politics, Bk. 4 Ch. 8 (3); Ch. 8 (9)

98 Aristotle, Politics, Bk. 4 Ch. 8 (3)
} 
virtuous. ${ }^{99}$ But aristocracy and polity "are not far from one another." ${ }^{100}$ Aristocracy and polity are also similar in the fact that they both generally need to be constructed instead of forming naturally. Aristotle specifies throughout Chapter 9 of Book 4 in Politics that polities should be constructed from the best legislative elements of oligarchy and democracy.

For his ideal state, Aristotle constructs a constitution that he believes to have the highest possibility of survival, "[f]or one should study not only the best regime but also the regime that is [the best] possible..." ${ }^{101}$ He believed that the most practical and realistic form of government is a constitutional government with the power in the hands of a strong middle class. This is because, in what is referred to as Aristotle's Doctrine of Mean, he believes that right conduct consisted of the average between two extremes, the middle ground between deficiency and excess. ${ }^{102}$ In the case of politics, the middle ground between the extreme of rich and poor is the middle class. ${ }^{103}$ In addition, what is commonly referred to as his Art of Acquisition also has a part to play in this conclusion. In Chapter 9 of Book 1 Aristotle talks about the fulfillment of basic needs, distinguishing between natural and unnatural desires. Natural desires he said consisted of food, shelter, and other necessities that were required in the management of households. Aristotle defined unnatural desires as the accumulation of money for its down sake. He disliked monetary currency because there was no limit to how much a person could acquire, believing this would lead to indulge in physical pleasure beyond the limits of reason and become consumed by it. He believed that those who possess the goods of fortune, strength, and looks in moderation, are "readiest to obey reason..." 104 In the case of wealth and politics, he thought of this as the middle class.

However, while Aristotle says that the best regimes are the ones closest to the middle and the worst the farthest away, he does mention that "while one sort of

\footnotetext{
${ }^{99}$ Aristotle, Politics, Bk. 4 Ch. 8 (9)

100 Aristotle, Politics, Bk. 4 Ch. 8 (10)

${ }^{101}$ Aristotle, Politics, Bk. 4 Ch. 1 (6)

102 Aristotle, Politics, Bk. 4 Ch. 11 (3)

103 Aristotle, Politics, Bk. 4 Ch. 11 (4)

104 Aristotle, Politics, Bk. 4 Ch. 11 (5)
} 
regime is more choice-worthy, there is often nothing to prevent another regime being more advantageous for certain [cities]." ${ }^{105}$ Aristotle was careful throughout Politics to admit that not all areas and cities are the same, each needing or defining different elements of governing. But he specifies that within legislation, no matter the constitution, the middle class should be mediator between the rich and poor, acting as an arbitrator. ${ }^{106}$

Balance was very important to Aristotle. His two theories of justice distributive and rectificatory - also have to do with maintaining or restoring balance. Distributive has to do with proportions: that all equals have equal shares of the subject in question. Aristotle describes that different constitutions use different concepts of merit for this equality; democracies see it as being free citizens, oligarchies see it as wealth or noble birth, and aristocracies see it as virtue. ${ }^{107}$ If an individual didn't have this merit, than they were not equals, thus inferior. Recificatory justice had to do with balancing out unequal distributions of gains and losses between two people. Aristotle uses this specifically to talk about rectifying wrongs in transactions. ${ }^{108}$

Next we will address Aristotle's perception of the causes and conditions of different constitutions coming about.

\section{Causes and Conditions}

Aristotle writes for both "how do" and "how should" certain constitutions form for the causes of these constitutions coming about. Generally, he emphasizes how the uncorrupt regimes "should" come about while explaining how the corrupt "do" come about. For his ideal state, the cause of its formation is straightforward: it's constructed. It does not exist naturally, though he does mention certain good aspects of his ideal state that exist within other constitutions.

\footnotetext{
105 Aristotle, Politics, Bk. 4 Ch. 11 (21)

106 Aristotle, Politics, Bk. 4 Ch. 12 (4) - (6)

107 Aristotle, Nichomachean Ethics, 86 1130b

108 Aristotle, Nichomachean Ethics, 87 - 88 1131b - 1132b
} 
Aristotle claims that "man is by nature a political animal,"109 and without being part of a city, an individual is only an animal. ${ }^{110}$ Aristotle believed that cities should come about not for the sake of living together, but for the sake of noble actions. ${ }^{111}$ He identifies three basic units - household, then village, then city - and states that associations depend on what kind of relationship is taking place. He identifies three kinds of personal relationships that can take place: master-slave, husband-wife, and parent-child. ${ }^{112} \mathrm{He}$, like Plato, believed in a hierarchy of kinds of people, noting that even nature generally consists of ruling and ruled elements. ${ }^{113}$ He believed slavery just when it is beneficial to all parties involved, and unjust when the individual's nature was not one of a slave. ${ }^{114} \mathrm{He}$ compares the relationship between the master and slave to soul and body; the master has rationality, while the slave lacks this and is controlled by baser emotions. ${ }^{115}$ In the husband-wife relationship, Aristotle did not have Plato's feminist thought in believing that men and women were equal, believing that man was by nature more fit to rule than women and should be the head of a household. ${ }^{116}$ Aristotle believed that the fatherson relationship should be based off of a child's love and respect for his father's age and wisdom. ${ }^{117}$ When describing each of these, Aristotle explains how all of these attributes of these relationships are related to how a relationship should be between a statesman and his free subjects.

Aristotle writes that in the past, because of the rarity of finding someone with virtue, monarchy was the first type of ruling to form. When a person was found, he was elected for kingship based on his "benefactions, something that is the work of good men."118 This was especially because population was so small. ${ }^{119}$ However,

\footnotetext{
109 Aristotle, Politics, Bk. 1 Ch. 2 (9)

110 Aristotle, Politics, Bk. 1 Ch. 2 (14) - (16)

111 Aristotle, Politics, Bk. 3 Ch. 9 (14)

112 Aristotle, Politics, Bk. 1 Ch. 12 (1)

113 Aristotle, Politics, Bk. 1 Ch. 5 (2); 41, Ch. 5 (8) - (11)

114 Aristotle, Politics, Bk. 1 Ch. 2 (2); Ch. 6 (5), Ch. 6 (10)

115 Aristotle, Politics, Bk. 1 Ch. 5 (6)

116 Aristotle, Politics, Bk. 1 Ch. 5 (7); Ch. 12 (1)

117 Aristotle, Politics, Bk. 1 Ch. 12 (3)

118 Aristotle, Politics, Bk. 3 Ch. 15 (11)
} 
when many arose who were similar in virtue, these people sought "something in common" and established a polity. ${ }^{120}$ He also writes that very few polities have actually existed in history.

From there, Aristotle theorizes that oligarchies arose because wealth became "a thing of honor." 121 He writes later that oligarchy arose "as a result of those who are unequal in some on respect conceiving themselves to be wholly unequal, for as they are unequal in regard to property they conceive themselves to be unequal simply."122 "Unequal" in this sense refers to superior. Oligarchy then became democracy, for "by bringing things into fewer hands through a base longing for profit, they made the multitude stronger, and so it attacked them and democracies arose."123 Basically, because of the consolidation of money into fewer and fewer hands, more people were estranged and angry and eventually chose to revolt. He writes that democracy formed "as a result of those who are equal in any respect supposing they are equal simply, for because all alike are free persons, they consider themselves to be equal simply."124

Aristotle writes that while as before, the people "put up with being ruled" because there were not enough of them to rise up against rulers, population has grown. ${ }^{125}$ Because of this population growth and because "good birth and virtue exist among few persons" and thus the ratio does not remain constant, he sees oligarchy and democracy as the most common form of constitution that arises. ${ }^{126} \mathrm{He}$ explains that these two regimes exist specifically because aristocracy can be seen as a type of oligarchy, and polity a type of democracy. This is because of aristocracy and polity being the virtuous forms, so they exist in much rarer circumstances and generally not without direct construction. Aristotle writes that equality is twofold: merit and numbers. But some people assume they are equal in all things because

119 Aristotle, Politics, Bk. 3 Ch. 15 (11)

120 Aristotle, Politics, Bk. 3 Ch. 15 (11)

121 Aristotle, Politics, Bk. 3 Ch. 15 (12)

122 Aristotle, Politics, Bk. 5 Ch. 1 (3)

123 Aristotle, Politics, Bk. 3 Ch. 15 (12)

${ }^{124}$ Aristotle, Politics, Bk. 5 Ch. 1 (3)

125 Aristotle, Politics, Bk. 4 Ch. 13 (11)

126 Aristotle, Politics, Bk. 5 Ch. 1 (14) 
they are equal in some things, while others believe they are unequal (superior) in all things because they are unequal in some. ${ }^{127}$ Aristotle has one other reason for oligarchy and democracy being the most common constitutional form: lack of a middle class. Because of factional infighting between the wealthy and the poor and no arbitrating element of the middle class, whichever has the majority will dominate the society and "conduct the regime to suit itself." $128 \mathrm{He}$ continually mentions that the tension between these two factions as causing a continual shift back and forth between oligarchy and democracy. Aristotle also describes that those who have established oligarchies and democracies within Greece have always done so to the advantage of the rulers, and not the community as a whole. ${ }^{129}$ Thus in his mind democracy and oligarchy are the most common forms. Aristotle relates oligarchies and democracies together quite a bit in Politics, as these are representative of the wealthy and the poor, who he sees engaging in factional conflicts routinely.

Aristotle writes that tyrannies arise when an individual is both a popular leader and a war general. However, he specifies that tyrannies were much more common in the past, but not so much now. ${ }^{130}$ He believes that tyrannies have a harder time existing nowadays because popular leaders are not often generals as well. ${ }^{131} \mathrm{He}$ argues that popular leaders in his day use the weapon of rhetoric, but are inexperienced in military matters and thus to do not try anything in that regard. ${ }^{132}$

Aristotle makes an interesting claim when it comes to citizenship in his ideal state. He shared Plato's view that those who had time to pursue virtue should be the ones to rule - as only those who were educated and habitual in the virtues would have right conduct - but took it a step further and applied this to citizenship as well. He believed manual laborers should not be granted citizenship because they are too busy with their work to devote enough time for education and the self-improvement

\footnotetext{
127 Aristotle, Politics, Bk. 5 Ch. 1 (12) - (14)

128 Aristotle, Politics, Bk. 4 Ch. 11 (17)

${ }^{129}$ Aristotle, Politics, Bk. 4 Ch. 11 (18)

${ }^{130}$ Aristotle, Politics, Bk. 5 Ch. 5 (6)

131 Aristotle, Politics, Bk. 5 Ch. 5 (7) - (11)

132 Aristotle, Politics, Bk. 5 Ch. 5 (7)
} 
necessary to govern. ${ }^{133}$ His theory of distributive justice enters here by reasoning that those who contribute most to this partnership of governing have a greater part in the city. ${ }^{134}$ I believe this reasoning was an attempt to cause a greater effort to strive for virtue, no matter what birth or wealth.

Reading this, one may have noticed the continual mention of the concern for those who have virtue and moral education. Like Plato, Aristotle was very concerned with moral education of his citizens. Unlike Plato, who thought that each class should have a particular education, Aristotle believed in a common education system where all were taught together. He writes, "[s] ince there is a single end for the city as a whole, it is evident that education must necessarily be one and the same for all, and that the superintendence of it should be common and not on a private basis..."135 Not only does he say this creates a greater sense of community, but he seems to imply that many more people were capable of being virtuous than what Plato believed.

Aristotle saw three ways in which men became excellent: nature, habit, and reason. ${ }^{136}$ To understand this, it would behoove us to look at his conception of the moral make-up of people. Aristotle believed in two parts of the soul as opposed to Plato's three parts; a rational part and an irrational part. ${ }^{137}$ He saw the irrational corresponding to the disposition of appetite, and the rational corresponding to intellect - the irrational needing to be subject to rational, of course. ${ }^{138}$ Aristotle believed in two types of virtue: intellectual and moral. ${ }^{139}$ He believed we learned intellectual virtues through instruction, and moral virtues by practice turning to habit. ${ }^{140}$ In addition to this, Aristotle saw two intellectual virtues: scientific and calculative, or deliberative. ${ }^{141}$ The first dealt with philosophy, theory, and the truths

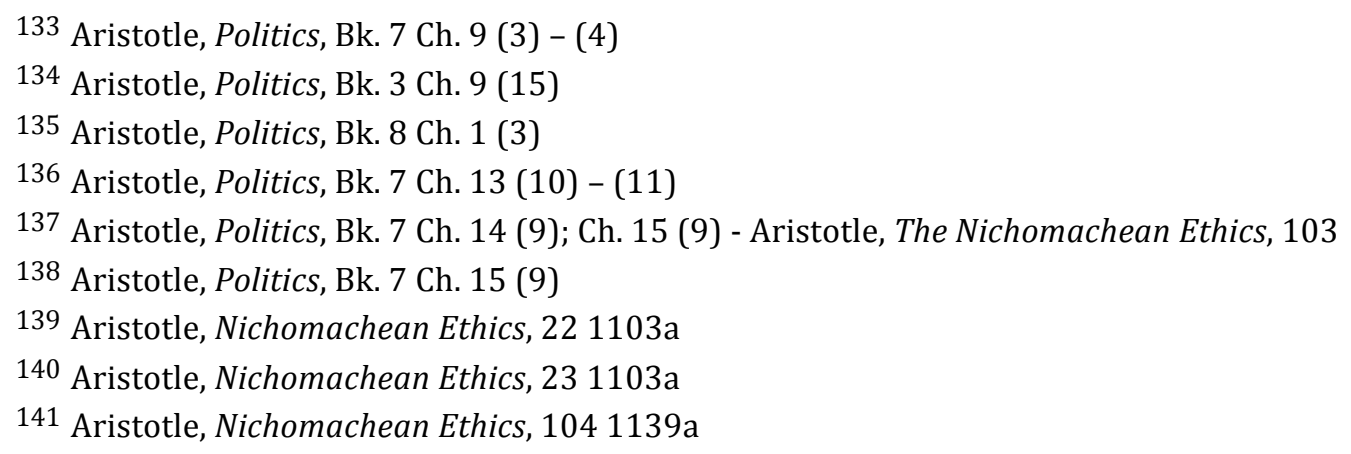


of sciences and mathematics, while the second aspect dealt with the social and political matters of human life. ${ }^{142}$ Aristotle attributed moral virtues to guiding rightness of purpose, while intellectual virtues were to be used for the correct way of coming to that purpose. ${ }^{143}$ Aristotle believed that a person could be virtuous only if both moral and intellectual virtues were used in all actions and decisions. ${ }^{144}$ This is often referred to as Aristotle's theory of Unity of Virtues. Aristotle writes that true justice only comes from a virtuous disposition, for those lacking in virtue are unable to perceive the just course of action in decisions.

There are a few final things that Aristotle addresses in crafting the ideal state. They are a bit interesting in the fact that they deal less with moral or structural issues as with size of the city, territory, placement, and divided city organization. This paper will not go into the physical details that Aristotle describes as they do not directly relate to the thesis, but a few points are important in understanding his conception of the ideal state. Throughout Chapter Ten of Book Seven, Aristotle talks about the need to divide the territory of the city into two parts, "one being common and the other for private individuals, and to divide each of these in two again. One part of the common territory should be for public services relating to the gods, the other for the expense of the common messes. Of the territory that belongs to private individuals, one part should be towards the frontiers, the other toward the city, so that, with two allotments assigned to each individual, all share in both locations." 145 He argues that possessions should not be commonly owned by everyone, "but rather should become common in use after the fashion of friends, and that none of the citizens should be in want to sustenance."146 $\mathrm{He}$ also details how different classes should be arranged within the city. ${ }^{147} \mathrm{He}$ deals with the subject of marriage and procreation throughout Chapter 16 of Book 7. He is basically concerned with procreation of those who are too young; he sees the prime age as 18 for women and

\footnotetext{
142 Aristotle, Nichomachean Ethics, 106 1139b; 108 1140b

143 Aristotle, Nichomachean Ethics, $1161144 \mathrm{a}$

144 Aristotle, Nichomachean Ethics, $1171144 \mathrm{~b}$

145 Aristotle, Politics, Bk. 7 Ch. 10 (11)

146 Aristotle, Politics, Bk. 7 Ch. 10 (9)

147 Aristotle, Politics, Bk. 7 Ch. 12
} 
between the ages of $35-37$ for men. ${ }^{148} \mathrm{He}$ also seems to indicate that children should always be subject to the will of the rulers, though he believes parents should still raise their own children. ${ }^{149}$

The final subject of "cause" on Aristotle will be his analysis on revolutions. Within each of these constitutions he describes certain weaknesses that lead to revolutions; he spends a considerable amount of time writing on their types, reasons, and specific issues that each regime effectively creates. He sees three types of revolutions: revolutions from one type of constitution to another, ${ }^{150}$ a change in a regime to be more or less of that kind of regime, ${ }^{151}$ or a change and/or eradication of a part of the regime. ${ }^{152}$ Aristotle writes generally that "regimes are overturned sometimes from within themselves and sometimes from outside, when an opposite sort of regime is either nearby or far away but powerful."153 However, he primarily addresses revolutions that occur for internal reasons that do no necessarily have to do with external forces.

Aristotle writes that revolutions occur primarily because of factional conflicts, which are conflicts between groups of different people. He mentions factions quite a bit throughout his Politics, referring specifically to oligarchy and democracy because this is where he believes it occurs most often - as this is intrinsically the conflict between the wealthy and the poor. Aristotle writes that factional conflicts arise from certain factions gaining strength, from factions becoming equal in a previously unequal power set up, or from small things. That a particular faction gaining strength causes a revolution is self-explanatory, and his mentioning of factions becoming equal in a previously unequal power situation is describing a scenario where the previously inferior faction now has strength enough to challenge the previously superior faction. ${ }^{154}$ This seems to be an offshoot of

\footnotetext{
148 Aristotle, Politics, Bk. 7 Ch. 16 (9)

149 Aristotle, Politics, Bk. 7 Ch. 16 (1) - (4)

150 Aristotle, Politics, Bk. 5 Ch. 1 (8)

${ }^{151}$ Aristotle, Politics, Bk. 5 Ch. 1 (9)

152 Aristotle, Politics, Bk. 5 Ch. 1 (10)

153 Aristotle, Politics, Bk. 5 Ch. 7 (14)

154 Aristotle, Politics, Bk. 5 Ch. 4 (11)
} 
particular factions gaining strength. As for small things causing revolutions, Aristotle seems to be referring to interpersonal fights between people causing factional conflicts (such as a cheating wife or husband, or a betrayal). ${ }^{155}$

Aristotle writes that revolutions have many causes and reasons. He writes that people aim for equality or for superiority, whichever they feel they have been slighted over. ${ }^{156} \mathrm{He}$ also writes that profit, honor, and avoidance of punishment (just or unjust punishment) are the things over which they engage in factional conflict for. ${ }^{157} \mathrm{He}$ describes the causes and beginnings points of revolutions as follows: fear, ${ }^{158}$ preeminence (or superiority), ${ }^{159}$ contempt, ${ }^{160}$ disproportionate growth of one particular part, ${ }^{161}$ electioneering, ${ }^{162}$ neglect of small things, ${ }^{163}$ and/or dissimilarity. ${ }^{164}$ However, Aristotle describes the greatest factional split as between virtue and depravity, but that the virtuous do not engage in revolutions because "because they are the few against the many," and like earlier stated do not have enough power to rise up against a more powerful faction. ${ }^{165} \mathrm{He}$ writes that regimes are also sometimes changed "through force, sometimes through deceit."166 Deceit used primarily, either in the beginning or later or both, to convince others to be willing in regard to the revolution taking place. ${ }^{167}$

All of the causes just described Aristotle uses in a general sense; he specifies further that each regime has specific reasons for undergoing revolutions. For kingships, Aristotle writes that they fall because of injustice, fear, and contempt on

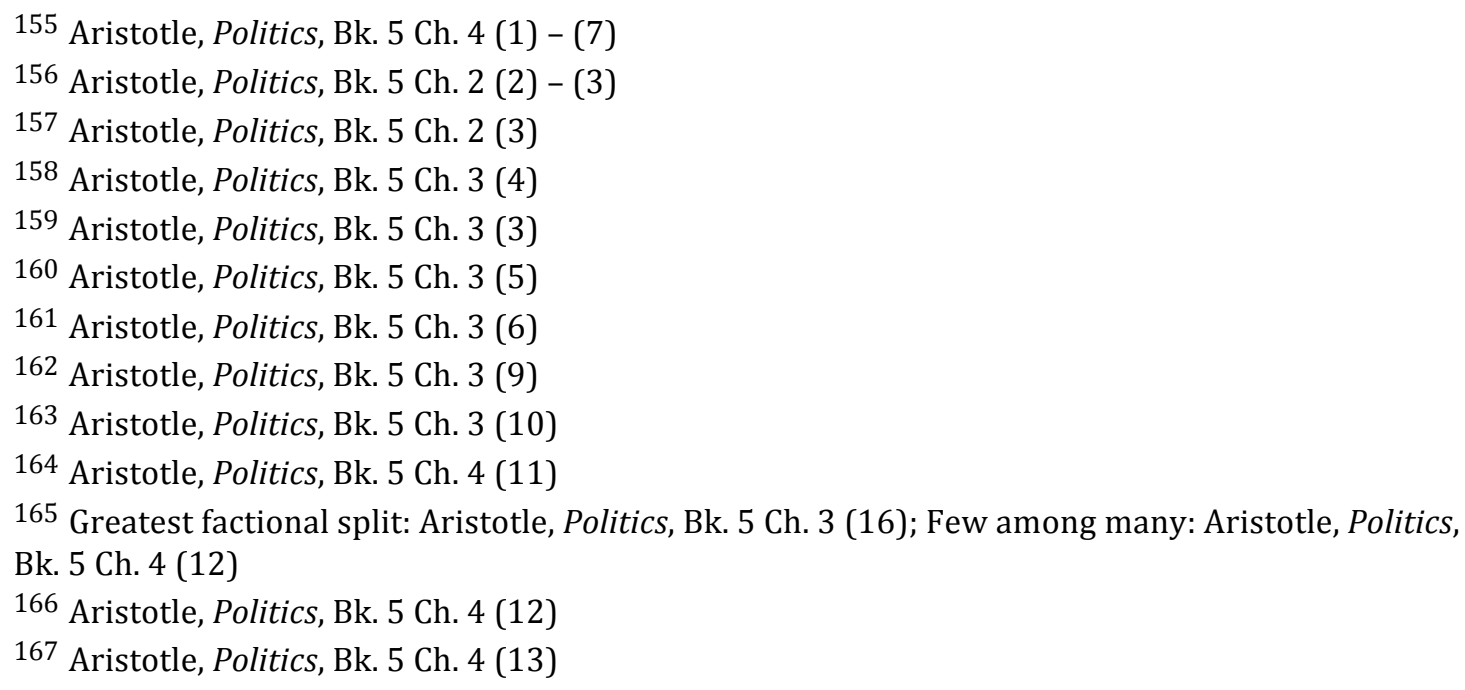


the part of the ruled. ${ }^{168}$ After all, kingships are based on the concept of a single individual being superior, which does not sit well with many people. Tyrannies are also brought down for similar reasons, Aristotle writes. ${ }^{169}$ He seems to imply that this is a bit more just in its undertaking.

Aristotle groups aristocracy and polity together as having similar reasons for their downfall. It is when "a certain multitude of persons who presume themselves to be similar on the basis of virtue" overtake the regimes. ${ }^{170}$ Furthermore, "polities and aristocracies are overturned above all through a deviation from justice in the regime itself." 171 This basically translates to meaning that polity was not "finely mixed" between the wealthy and the poor, and for aristocracy virtue is included as well. ${ }^{172}$ From there, Aristotle sees that whichever faction with the most power will end up pulling more power to itself and swaying these regimes either in the direction of oligarchy or democracy. ${ }^{173}$ He sees this as happening in small steps as opposed to an armed conflict. ${ }^{174}$

Oligarchic revolutions happen in two ways, Aristotle writes: treating the multitude unjustly, and expending wealth into wanton living. ${ }^{175}$ In expanding upon treating the multitude unjustly, Aristotle writes that this can happen from within as other oligarchs feel they are being treated unfairly and wish for more power themselves; basically, because of rivalry. ${ }^{176}$ As for wanton living, Aristotle believes that people like this will "attempt sedition" and "either aim at tyranny for themselves or help institute it."177 It seems as though Aristotle means that these types of oligarchs will makes deals with others, all with the aim of gaining more wealth.

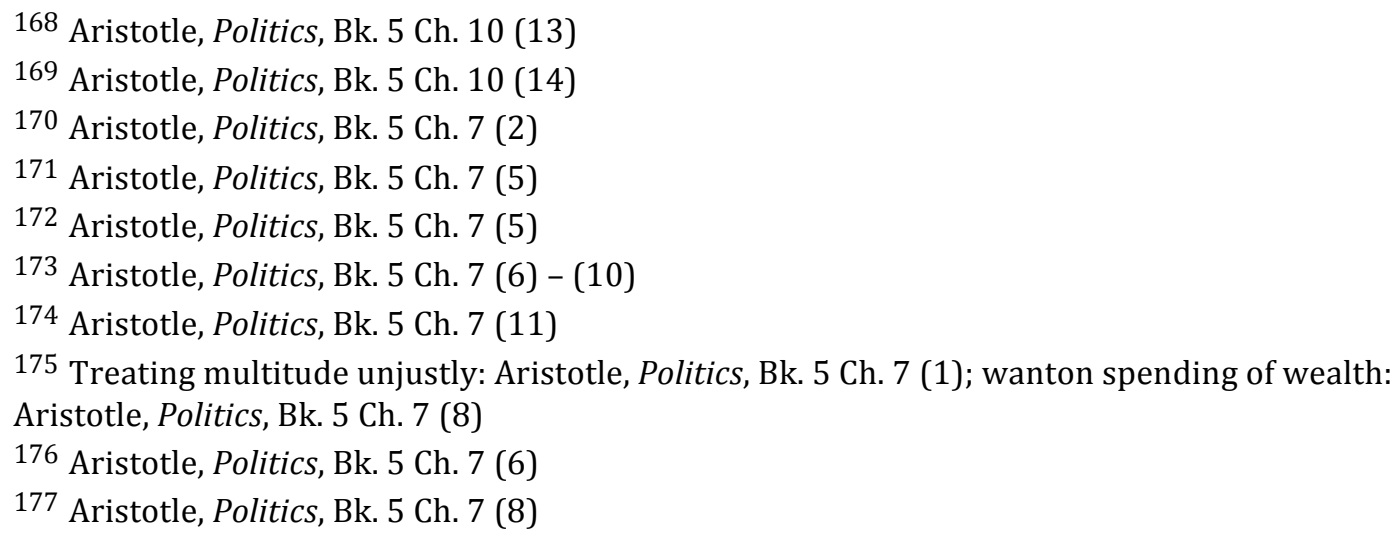


Finally, Aristotle describes revolutions in democracies as occurring because of the wanton behavior of popular leaders. ${ }^{178}$ In one way, Aristotle writes, they continually harass property owners into causing them to form an alliance against the popular leader. In another, Aristotle writes that these popular leaders "egg on the multitude publicly." 179 He also writes that democracies undergo revolutions from "traditional" democracy to the "most recent sort."180

In summary, Aristotle believed that monarchies rose because of the limited amount of good people to choose from, but as population grew the power shifted. He believed that polities formed from a rise in virtuous people, followed by a downgrade into oligarchy as people valued wealth as supreme. Democracy came from the revolution that followed, and Aristotle describes a continual shift back and forth from democracy to oligarchy and back again. Aristocracy and polity he describes as similar, but also needing more of an element of creation and organization to actually exist. Tyranny, Aristotle concludes with, is the rise of a popular leader with military power, but is becoming an outdated concept with the separation between executive and military forces. Finally, Aristotle discusses revolutions, why they occur, their causes and reasons, and the specifics that exist within each type of regime. With all of this in mind, this paper will turn to Aristotle's perceived effects of these constitutions.

\section{Effects and Lessons}

The effects section on Aristotle will address two subjects: the preservation of regimes and the lessons to be drawn from his writings. Because Aristotle wrote for the purpose of creating the best possible form of each regime, he was more focused upon what could be improved or fixed within each regime - such as having a "middling" element. In essence, the effects of regimes are the "fixes" that are needed to help the regime survive. Thus, the lessons that can be drawn from his writings can be grouped into two main categories: (1) the importance of a virtuous populace;

\footnotetext{
178 Aristotle, Politics, Bk. 5 Ch. 5 (1)

179 Aristotle, Politics, Bk. 5 Ch. 5 (1)

180 Aristotle, Politics, Bk. 5 Ch. 5 (10)
} 
and (2) the importance of a middle class that exhibits moderation in taste and desires. I will describe these below.

First, as Aristotle perceives general reasons for revolutions, he similarly describes several general factors that are important in preservation of regimes. He first writes that should be no transgression of the laws, and that diligence must be paid even to the smallest transgression. He relates this to small expenditures in someone's expenses adding up to be much bigger than what the mind conceives. ${ }^{181}$ He also writes "nothing should be devised against the multitude, for they are thoroughly refuted by the facts." 182 He also specifies that the public must be treated well (as revolutions are often spurned by fear, hated, contempt, arrogance, etc). ${ }^{183}$ He stresses the importance of always making sure everyone knows of what destroys the regime, promoting just enough of a sense of fear to make people want to guard the well being of their regime. ${ }^{184}$ Aristotle also writes, as would seem obvious after all the care Aristotle has taken to write about it, that one must guard against rivalries in factions; to always watch and take care that small things to not cause huge revolutions to take place. ${ }^{185} \mathrm{He}$ also is a proponent of short office terms; also, to make sure power is crafted in the fashion of laws so that particular people do not necessarily have preeminence over their peers. ${ }^{186}$ Aristotle also writes that it would be important to make sure the ruling body is always the most variable mix one can achieve of all the types of citizens within a regime - or at least have a large middle class involved. ${ }^{187}$ Aristotle finally stresses that ruling offices must not have a profit involved for those who are in positions of power. This way, with the poor not necessarily attracted to offices of power because there is no profit involved, the well off are more inclined to rule and more of an aristocracy could form. ${ }^{188}$

\footnotetext{
181 Aristotle, Politics, Bk. 5 Ch. 8 (2) - (3)

182 Aristotle, Politics, Bk. 5 Ch. 8 (4)

183 Aristotle, Politics, Bk. 5 Ch. 8 (5)

${ }^{184}$ Aristotle, Politics, Bk. 5 Ch. 8 (8)

185 Aristotle, Politics, Bk. 8 Ch. 5 (9)

186 Aristotle, Politics, Bk. 8 Ch. 5 (12)

187 Aristotle, Politics, Bk. 8 Ch. 5 (14)

188 Aristotle, Politics, Bk. 8 Ch. 5 (15) - (18)
} 
Aristotle believes that virtuous regimes will, of course, be virtuous and achieve supreme happiness. Corrupt regimes will not be virtuous or happy, and considering his large discussion upon revolutions, he does not seem to view them as very stable either. A state will be virtuous if Aristotle's ideal friendship exists between the citizens and the ruler(s). The effects of enacting Aristotle's ideal state will also be a life of virtue and happiness, where he probably sees as more likely to have supreme happiness than other virtuous regimes.

As has been probably seen, Aristotle has similar lessons to Plato. He does seem less concerned with the destructive power of rhetoric than Plato, because as stated above, Aristotle thinks with military and ruling power not often in the same hands, tyrants are less likely to arise. However, he does not belittle the huge influence that rhetoric does have, often mentioning it. I think there is something to be said for the fact that he wrote, at least Politics, for the purpose of helping lawmakers make a regime better. This creates more of a focus on improving elements and less of a focus, as Plato does, on negative aspects that can be done or happen. This is not to say that Aristotle ignores the problems and flaws - quite the opposite, for it is only focusing on these flaws and trying to improve them can one create a better state.

Another very similar element to Plato is Aristotle's concern for education. Aristotle also sees the effects of good education causing a more ideal state, for "the habits that make a man excellent are essentially the same as those that make him a political or kingly [ruler]." ${ }^{189}$ However, as mentioned, Aristotle has a different view than Plato, believing that all (men) should be educated equally, to both create more cohesion within a community and more excellent people. Thus, with a more educated and excellent populace, as state will be more likely to have excellent rulers.

The second lesson, as has been mentioned, concerns the importance of a strong middle class with moderate desires and tastes. This stems from Aristotle's worry of factional conflict between the wealthy and the poor. A "middling element"

189 Aristotle, Politics, Bk. 3 Ch. 18 (1) 
would help tame this conflict because they are "readiest to obey reason..."190 if people possess fortune in moderation, and would act as arbitrators between the wealthy and the poor. If a strong middle class was created, he believes it will help the regime survive and avoid revolution. This is especially involved in oligarchic and democratic regimes, which are the epitome of "wealthy" and "poor" in a regime.

These are the effects that Aristotle conceives of different regimes; the institutions that need to be in place to keep the regime from turning to revolution. Aristotle does focus on what he believes is the best regime, but more so focused on making each individual regime best possible. In this regard, he is very applicable in understanding the problems of democracy specifically as well as forming theories on the flaws of democracy in relation to what can be done to improve them. But before turning to this, we have one last writer to address: now we will turn to Thucydides.

\section{THUCYDIDES}

Thucydides' famous text, The History of the Peloponnesian War, signified a new genre of writing: critical political history. Surrounding the events of the war between Athens and Sparta, Thucydides' History is renowned for its critical attention to facts and singular focus to record the truth and reality of events and situations. He writes that, “...with regard to my factual reporting of the events of the war I have made it a principle not to write down the first story that came my way, and not even to be guided by own general impressions; either I was present myself at the events which I have described or else I heard of them from eye-witnesses whose reports I have checked with as much thoroughness as possible. Not that the truth was easy to discover: different eye-witnesses give different accounts of the same events, speaking out of partiality for one side of the other or else from imperfect memories."191 Unlike previous authors, he did not blame events on the

\footnotetext{
190 Aristotle, Politics, Bk. 4 Ch. 11 (5)

191 Thucydides, History of the Peloponnesian War, trans. Rex Warner (New York: New York, 1954), 48 $(\mathrm{I}, 22)$
} 
Greek gods, but came from the perspective that human behavior and actions caused events to happen. ${ }^{192}$ Yet how does this help us for the purpose of this paper, which focuses on the applicability of political philosophy, when Thucydides is a selfprofessed historian concerned with facts?

The first part to answering this question has to do with Thucydides' goal in writing his History. He writes that he hopes, "these words of mine are judged useful by those who want to understand clearly the events which happened in the past and which (human nature being what it is) will, at some time or other and in much the same ways, be repeated in the future. My work is not a piece of writing designed to meet the needs of an immediate public, but was done to last for ever."193 He wrote his history as an assessment of past practices to better understand and (perhaps) prepare for the future. ${ }^{194}$ In this regard, relating to modern day democracy, his writing about the effects of war on Athenian democracy and the Greek global world has high significance.

The other key issue involved is the question of philosophy. Does Thucydides, being a self-professed historian, belong in the realm of philosophy? The simple recordation of facts can be interpreted in order to help understand current events or trends, but it does not help with this paper in regard to understanding classical political theory on democracy. This is where the 'but' arrives; there are many contemporary scholars who believe that Thucydides was trying to relay moral meaning while recording events. This is actually a big debate in the realm of Thucydidian scholarship. This basic arguments for Thucydides relaying moral meaning in his recording of events is outlined in David Cohen's article, "Justice, Interest, and Political Deliberation in Thucydides.” He believes that Thucydides' History is really "a commentary on war, politics and empire rather than a

\footnotetext{
192 Thucydides, History of the Peloponnesian War, 20

193 Thucydides, History of the Peloponnesian War, 48 (I, 22)

194 Josiah Ober, “Thucydides' Criticism of Democratic Knowledge," in Nomodeiktes: Greek Studies in Honor of Martin Ostwald ed. Ralph M. Rosen and Joseph Farrell (Ann Arbor: University of Michigan Press, 1993), 85
} 
comprehensible historical account of a particular war."195 Cohen argues that Thucydides' moral arguments are not stated, but become apparent through "deliberate thematic structuring" of the narrative and the speeches with "complex verbal patterns" that serve to draw connections between events. Cohen also points out the way in which Thucydides pays extreme attention to certain events while seeming to pass over others with the brief description, which also seems to indicate Thucydides is trying to show something. ${ }^{196}$ As M. I. Finley writes in Aspects of Antiquity, "there is a passion for the most minute detail: minor commanders, battle alignments, bits of geography and the like, so that a mere index of names occupies thirty-two double column small octavo pages. On the other hand, there are astonishing gaps and silences, whole chunks of history that are left out altogether..." 197 Cohen also argues that Book III within the Peloponnesian War has much to say about Thucydides' moral arguments. ${ }^{198}$ Cohen also argues that in Book III there is lot of understanding to be found in the nature of his commentary on political deliberation, statesmanship, and empire when comparing antinomies of justice vs. interest, revenge vs. moderation, and calculation vs. action. ${ }^{199}$ It is also of interest to look at the way that Thucydides relays speeches to their exact detail; how could he have done this from memory, or even further, from the memories of others? There is something to be said for remembering certain phrases and the main points of speeches, but it raises red flags that Thucydides describes them in such detail. But this provides all the more reason to draw philosophical elements from Thucydides' writing. Thucydides himself writes that while he keeps as "closely as possible to the general sense words," he also, because of the difficult of exact portrayal, makes the speakers say what, in his opinion, "was called for by each

\footnotetext{
195 David Cohen, "Justice, Interest, and Political Deliberation in Thucydides," Quaderni Urbinati di Cultura Classica 16 (1984), pp. 36

196 David Cohen, “Justice, Interest, and Political Deliberation in Thucydides," pp. 36

197 M. I. Finley, Aspects of Antiquity, (New York: The Viking Press, 1968), 52; a similar statement can also be found in David Kagan The Great Dialogue: History of Greek Political Thought, (New York: The Free Press, 1965): 97 - 98

198 David Cohen, “Justice, Interest, and Political Deliberation in Thucydides," pp. 37

199 David Cohen, “Justice, Interest, and Political Deliberation in Thucydides," pp. 36 - 37
} 
situation."200 Donald Kagan writes in The Great Dialogue: History of Greek Political Thought, "the historian's own opinions may be sought in the speeches he puts into the mounts of his characters." 201 Finley writes that Thucydides' speeches "are in direct discourse, and very much abridged - a perfectly legitimate procedure. But they are also, without exception, written in the language and style of Thucydides, and that gives the modern reader, at least, some twinges of conscience."202 Intuitively, it would seem as though Thucydides' speeches have more to them then simple explanation.

This understanding of moral and political themes in Thucydides will be discussed further below. For now, let it stand that while Thucydides is first a historian, he has many elements in his writing that can be interpreted in some basis as relaying philosophical meaning. As Finley writes, Thucydides is "in the last analysis a moralist's work."203 Thus we can learn from him for the purposes of this paper.

\section{Description}

The Peloponnesian War follows the events of the Athenian and Spartan war of 431 - 404 B.C.E, but only records until 411 B.C.E. where Thucydides abruptly stopped writing. He specifically focused upon the effects of war on the democracy of Athens, and the oligarchy of Sparta. Josiah Ober writes that Thucydides' development of critical political history "allowed him to take an epistemological stance that he believed provided a useful and meaningful way to understand the past and simultaneously explained why the system of democracy failed under the pressures of war." 204 The main conclusions often taken from Thucydides' writings are in the realm of International Relations theory, especially within the relationship between human nature to power and war. Thucydides is often credited, whether it was his intention or not, as being the father of "political realism," the theory that the

\footnotetext{
200 Thucydides, History of the Peloponnesian War, 47 (I 22)

201 Donald Kagan, The Great Dialogue: 96

202 Finley, Aspects of Antiquity, 54

203 Thucydides, History of the Peloponnesian War, 32

204 Ober, “Thucydides' Criticism of Democratic Knowledge," 81-82
} 
relations of nations are based on might rather than right. However, authors like Cohen reject this idea that Thucydides was an "amoral realist or disinterested in moral questions" or a "proponent of power politics." 205 Instead, as already mentioned, Thucydides was probably relaying moral meaning within his articulation of events. This paper would like to put forth the idea that while Thucydides may not have believed that "might makes right," as he is often credited, he was very aware of how power and influence shaped a great deal of political reality. While Thucydides is mainly concerned with the relationship between states, within this are underlying accounts of different types of political systems specifically democratic Athens and oligarchic Sparta. Thucydides also focuses upon the differences in regime type leading to different behavior in explaining international events. These accounts of the differences between states will be used in this paper.

Thucydides first points out the differences in regime decision making in scenarios where these regimes decide to go to war. Athens, for example, takes two days to decide on defending Corcyra at the beginning of History. Sparta, in contrast, decides to engage in war with Athens the very day the question is posed. ${ }^{206}$ By way of political deliberation, Thucydides describes the national identities of Sparta as revenge and of Athens as moderation.

Thucydides also sets up the national identity of Athens as being very selfinterested (the Athenians even professing it themselves). The most famous passage concerning this interplay is the Melian Dialogue, where Athens and the island of Melos debate justice vs. self-interest. ${ }^{207}$ Athens voices the side of self-interest, saying that it is in the Melians own self-interest to surrender to Athens because the Melians would not stand a chance against the Athenian army. The Melians, in contrast, argue the side of justice, hope, and honor. In the end, the Melians do not surrender and the Athenians end up massacring the entire city. ${ }^{208}$ The emblematic sentence seems to

\footnotetext{
205 Cohen, "Justice, Interest, and Political Deliberation in Thucydides," pp. 37

206 Cohen, "Justice, Interest, and Political Deliberation in Thucydides," 42

207 Thucydides, History of the Peloponnesian War, 400 - 408

208 Thucydides, History of the Peloponnesian War, 408 (116)
} 
be, spoken by the Athenians, “'...justice depends on the equality of power to compel and that in fact the strong do what they have the power to do and the weak accept what they have to accept."'209

In contrast to this, Sparta seems to be set up as a regime more built on justice or morality. For example, when Sparta is deliberating on whether to go to war with Athens, there are many speeches made that it would not be in the Spartan's selfinterest to go to war. The Athenians had just broken the treaty by fighting against a Spartan ally. Yet the Athenians call the Spartan assembly only a deliberative body, not a court of law: "You assembly is not a court of law, competent to listen to pleas either from them or from us. Our aim is to prevent you from coming to the wrong decision on a matter of great importance..." 210 David Cohen writes that the Athenians declare self-interest as requiring actions to maintain it, and " $t$ t]hey claim that the Spartans are making a mistake in allowing themselves to be persuaded by considerations of Justice..." ${ }^{211}$ Athens also say that self-interest requires careful deliberation. ${ }^{212}$ The Spartan King, Archidamus, cautions the rest of his Spartans by explaining the important, practical elements of what it would take for Sparta to not only engage in a war with Athens, but to win (which doesn't look great). ${ }^{213}$ This is soon contrasted by a speech by a Spartan named Sthenelaides who evokes the morality of justice - that Sparta should come to her allies' aid - to convince Sparta to go to war. He also declares that Sparta should free the Greek cities from oppressive Athenian rule. ${ }^{214}$ Sparta soon votes to engage in the war, a decision that describes the Spartan characteristic of morality. Sparta is also described as being slow and cautious when making decisions (though, as mentioned above, still based on

\footnotetext{
209 Thucydides, History of the Peloponnesian War, 402 (89)

210 Thucydides, History of the Peloponnesian War, 78 (73)

211 Cohen, "Justice, Interest, and Political Deliberation in Thucydides," 40

212 Cohen, "Justice, Interest, and Political Deliberation in Thucydides," pp. 40 - 41

213 Cohen, "Justice, Interest, and Political Deliberation in Thucydides," 41; Thucydides, History of the Peloponnesian War, 82 - 86 (I 80 - 85)

214 Thucydides, History of the Peloponnesian War, 86 (I 86)
} 
morality or revenge). ${ }^{215}$ This contrast between national identities is continually emphasized throughout Thucydides' History. ${ }^{216}$

Thucydides is also very critical of the way that Athens makes decisions. As Josiah Ober states in his article "Thucydides' Criticism of Democratic Knowledge," Athens relied upon opinion of the masses to interpret, or to form, what was truth and what was lies through the process of their assembly. ${ }^{217}$ Ober interprets Thucydides as pointing out this as highly problematic; Athenians were often taken to believing ridiculous things, and the speeches that were heard by the Athenian assembly were not necessarily correct. ${ }^{218}$ Thucydides shows that speeches made to the Athenians are not so much made of bold faced lies, but a "mish-mash of truths, half-truths, and outright errors or lies." 219 With the question of separating truth from lies, then, a real problem arises. Ober argues that Thucydides is pointing out a problem with democratic knowledge, that "citizen masses are unable to determine truth accurately or to determine congruity of interest by listening to speeches because they have no way of testing for either quality."220 Thucydides seems to point out, again and again through the speeches within his History, the fact that Athens' method of understanding reality is flawed. Josiah Ober writes that, with this, "Thucydides has established for his readers the existence of a fatal structural flaw in the edifice of democratic ways of knowing and doing; and this flaw is a key to his criticism of Athenian popular rule." 221 Even in his introduction Thucydides relates his scorn of Athenians uncritically believing stories that pass their way. ${ }^{222}$ With that, let us to turn to Thucydides' causes and conditions of Athens and Sparta.

\footnotetext{
215 Thucydides, History of the Peloponnesian War, 84 (I 83 - 85)

216 Another insightful piece about the interplay between Athens self-interest and Spartan morality can be found in Thomas Pangle and Peter Ahrendsdorf, Justice Among Nations, (Lawrence: Kansas, 1999): $13-32$

217 Ober, "Thucydides' Criticism of Democratic Knowledge," 83

218 Ober, "Thucydides' Criticism of Democratic Knowledge," 84 - 85

219 Ober, "Thucydides' Criticism of Democratic Knowledge," 90 - 91

220 Ober, "Thucydides' Criticism of Democratic Knowledge," 91

221 Ober, "Thucydides' Criticism of Democratic Knowledge," 91

222 Thucydides, History of the Peloponnesian War, 46 (I 20)
} 


\section{Causes and Conditions}

Thucydides describes Attica, or the beginnings of Athens, as being a stable society because it had poor soil. In this regard, the civilization was able to grow relatively unharmed, without political disturbances, even as refugees from other wars came to inhabit this place. Thucydides describes Attica as growing so large that colonies had to be sent out in order to keep up with the population growth. ${ }^{223}$ Thucydides then describes robbery on the seas and on land, and it became common for all to carry weapons. ${ }^{224}$ Athens was the first city to lay down arms and live a life of luxury and relaxation. ${ }^{225}$ Thucydides then illustrates that the outbreak of the Trojan War left the Greek world in a state of instability and constant resettlement, and that during this period Athens colonized most of Ionia while Sparta colonized most of Italy, Sicily, and a few other places. ${ }^{226}$

Thucydides writes that the old form of government was "hereditary monarchy with established rights and limitations," but as the Greek world grew more powerful and wealth became more important, tyrannies were established in most cities. ${ }^{227} \mathrm{He}$ also points out the importance of naval power arising during this time, but also that the nature of the tyrant is not cooperative so there was not much progress in the way of enterprise. 228 "Finally, however, the Spartans put down tyranny in the rest of Greece," Thucydides writes, but soon the Persians invaded and they fought first the Athenians, and then the Spartans. ${ }^{229}$ Thucydides describes that it was by a combined effort between Sparta and Athens that the Persians were repelled, and after the war the rest of the Greek world split to follow either Sparta or Athens. ${ }^{230}$ "For a short time the war-time alliance held together, but it was not long before quarrels took place and Athens and Sparta, each with her own allies, were at

\footnotetext{
223 Thucydides, History of the Peloponnesian War, 36 (I 2)

224 Thucydides, History of the Peloponnesian War, 38 (I 6)

225 Thucydides, History of the Peloponnesian War, 38 (I 6)

226 Thucydides, History of the Peloponnesian War, 42 - 43 (I 12)

227 Thucydides, History of the Peloponnesian War, 43 (1 13)

228 Thucydides, History of the Peloponnesian War, 43 - 45 (I 13 - 17)

229 Thucydides, History of the Peloponnesian War, 45 (I 18)

230 Thucydides, History of the Peloponnesian War, 46 (I 18)
} 
war with each other," Thucydides writes, and describes that from the end of the Persian War to the beginning of the Peloponnesian War that there were some intervals of peace, but on the whole these two powers were fighting. He makes sure to point out that these states were always prepared militarily, and gained their experience "in the hard school of danger."231 This is the background that Thucydides gives for the Peloponnesian War.

There are two other important points to keep note of, which have to do with the reasons and conditions for growth of Athenian power. First off, an Athenian envoy states that Athens grew to power and refuses to give up this power because of honor, interest, and security (or fear). ${ }^{232}$ Secondly, Athens also professes its growth of allies (and thus empire) came by way of countries fleeing to Athens for aid of their own accord when Persia invaded and Sparta was unwilling to fight to the end. ${ }^{233}$ After the Persian War, Athens refused to give up its empire because of fear its allies would go the Spartan side. But it was also, of course, involved in the concern for interest and profit.

Thucydides also places a big emphasis on the influence of individuals in creating different national identities within these regimes. ${ }^{234}$ Thucydides seems more so focused upon Athens in this regard than Sparta - which seems to make sense, considering democratic Athens has a lot more influence via citizenry. Athens' national identity is often said to be found in the character of Pericles (or Perikles) of Athens. He was the general of Athens at the beginning of the war, and had strategies based on caution and conservatism. Thucydides seems to have a deep respect and admiration for Pericles, writing, "when Pericles was at the head of affairs the state was widely led and firmly guarded, and it was under him Athens was at her greatest. And when the war broke out, here, too, he appears to have accurately estimated what the power of Athens was." Thucydides cites Pericles as saying Athens would be victorious if she "bided her time and took care of her navy," "avoided...add[ing] to

\footnotetext{
231 Thucydides, History of the Peloponnesian War, 46 (I 18)

232 Thucydides, History of the Peloponnesian War, 80 (I 75 - 76)

233 Thucydides, History of the Peloponnesian War, 80

234 Donald Kagan also writes this in The Great Dialogue: 105; but argues that Thucydides saw individuals not so much as shaping states so much as shaping history.
} 
her empire," and "did nothing to risk the safety of the city itself." Thucydides writes that because of Pericles' intelligence and integrity, he could respect the liberty of citizens but "at the same time hold them in check" to not act in outrageous ways. ${ }^{235}$ In this regard the collected and intelligent Pericles shapes the national identity of Athens. Some scholars even argue that Thucydides saw the democracy under Pericles as not quite a democracy, with power concentrated in more capable hands, and admired Athens during this time because of Pericles' rule. ${ }^{236}$ But this does not last forever, as the next section on effects will show.

\section{Effects and Lessons}

The effects of the differences between these regime types are straightforward: the Peloponnesian War. However, the differences in the domestic politics of these two regimes help explain the reasons for the external war. For this section this paper will be highlighting how Thucydides reinforces the conclusions of the other philosophers with the themes of poor decision-making, the high susceptibility of democracy to specific individual personalities, the power struggles that arose over zeal for self-profit and especially between wealthy and poor factions, as well as the destruction of morality that results from war. In this similar lessons can be derived: quality education and ability for critical analysis, protections against the appetite for wealth, protections against the infighting between the wealthy and poor, as well as a prevention of excessive battle and warfare.

Thucydides writes that the primary reason Sparta went to war with Athens was because of Spartan fear of Athenian power. ${ }^{237}$ It is also of interest that Sparta took issue with the oppression of the Athenian empire, striving to free Greek states, though it could be argued that this was simply rhetoric for a call to arms. On the flip side, Thucydides also seems to blame the poor decision making power of the Athenian assembly as contributing to the exacerbation of the war. Thucydides shows that, as the result of poor Athenian gathering of facts and information, Athens

235 Thucydides, History of the Peloponnesian War, 163 - 164 (II 65)

236 Kagan, The Great Dialogue, 106 - 108

237 Thucydides, History of the Peloponnesian War, 49 (I 23) 
was prone to making incorrect judgments about actions to be taken. As was probably obvious, the discussion above of opinion-based facts and the half-truths of speeches within the Athenian assembly caused eventual errors and bad policy decisions. This is the beginning of Athenian degradation.

The other side of Athenian degradation involves the influence of specific individuals in creating national identities. As already mentioned, Pericles was highly regarded by Thucydides in leading Athens using moderation and careful thinking. Thucydides even states he believes that Athens, under Pericles' guidance, would have won the war. But Thucydides writes that after Pericles' death, his successors "did the exact opposite," and enacted policies, led by private ambition and private profit, "which were bad both for the Athenians themselves and for their allies." For example, after the death of Pericles, when Mytilene revolts from Athens, Athens "in their angry mood, decided to put to death not only those now in their hands but also the entire adult male population of Mytilene, and to make slaves of the women and children."238 This is incredibly contrary to earlier Athenian descriptions of selfinterest and moderate thinking, where Pericles held tempers in check. However, the Athenian Assembly does return the next day to reconsider, wondering if this judgment was too harsh. This begins a debate where Cleon, an Athenian general, comes forward to convince the Athenians that it would be bad to go back on their word. Cleon declares that it would be a worst sort of thing to pass decrees and then go back on them, and begins to relate Athens to a tyranny that needs to control it's subjects. ${ }^{239}$ Cohen states that "Cleon's rhetorical tactics conceal, however, is that his conception of justice is in reality no more than blind vengeance based upon anger, dispensing with the niceties of determining guilt or innocence in a fair trial." 240 Cleon is an important character who takes over the direction of Athens after Pericles' death. Thucydides did not look kindly upon him. As Finley writes, Thucydides "intended to represent not only Cleon but the demagogue as a type, the kind of leader who took over when Pericles died and, in the historian's judgment,

238 Thucydides, History of the Peloponnesian War, 212 (III 36)

239 Thucydides, History of the Peloponnesian War, 213 (III 37)

240 Cohen, "Justice, Interest, and Political Deliberation in Thucydides," 47 
led Athens to folly and ruin." ${ }^{411}$ Athens' identity of moderation unravels under these leaders as "to think of the future and wait was merely another way of saying one was a coward; any idea of moderation was just an attempt to disguise one's unmanly character; ability to understand a question from all sides meant that one was totally unfitted for action." 242 The characteristic of revenge and haste that is exemplified in the characters of Sthenelaides and Cleon begin to take over the Greek world as the war drags on and on. Plato's concern for democracy being the gateway into tyranny is echoed in Thucydides' words.

It is of interest to note that Sparta offered a truce at one point to the Athenians in an attempt to end the war, to which the Athenians declined. This begins because Spartan warriors were captured ${ }^{243}$ - first off, a huge insult to Spartan ideology of death before losing a battle - and Spartan generals in response decide to negotiate with the Athenians to both get their men back and begin a treaty of peace with the Athenians. ${ }^{244}$ Thucydides specifically describes that the Spartans assumed that the Athenians wanted to make peace and gladly "embrace the opportunity," but that in actuality the Athenians were experiencing a winning streak and thus "aimed at winning still more."245 The Athenians, specifically led by Cleon, list several of their demands in return to the Spartan request. When the Spartans ask for a committee to be put together to negotiate each point and find agreement, Cleon comes "down upon them in full force," and says he had always known their intentions were not "upright." The Spartans eventually give up and leave. ${ }^{246}$ This is a very poignant moment, where the war could have been stopped but Athenian greed, and specifically Cleon's arrogance, causes it to continue.

Thucydides writes of demagoguery and power struggles within Athens that causes a loss of control over the conduct of affairs, to which Athenian rulers "began

\footnotetext{
241 Thucydides, History of the Peloponnesian War, 31

242 Thucydides, History of the Peloponnesian War, 242 (III 82)

243 Thucydides, History of the Peloponnesian War, 270 - 273 (IV 11 - 14)

244 Thucydides, History of the Peloponnesian War, 273 - 276 (IV 15 - 20)

245 Thucydides, History of the Peloponnesian War, 277 (IV 21)

246 Thucydides, History of the Peloponnesian War, 277 (IV 21 - 22)
} 
to bring confusion into the policy of the state."247 In the above description, where Cleon attempts to convince the Athenians to keep to their original decision about Mytilene, he is contrasted by a character named Diodotus. Diodotus evokes the Athenian identity of self-interest to convince the assembly that wiping out the entire Mytilene race is the wrong decision. ${ }^{248}$ Diodotus ends up turning the views of the Athenian assembly around and they send out ships to counteract the orders of the ships sent out the day before. ${ }^{249}$ This inability to stick with a decision plagues the Athenians for the rest of the war, as do bad decisions on the part of the leaders. Thucydides writes that these policies "naturally led to a number of mistakes, amongst which was the Sicilian expedition," that ends up turning the whole Greek world, including Persia, against the Athenians. Thucydides writes that those "who had not been allied with either side thought that...they ought not to keep out of the war any longer...since the Athenians, in the view of each state, would have gone against them, if they have been successful in Sicily..."250 Thucydides makes the statement of effect pretty clear. And "in the end it was only because they had destroyed themselves by their own internal strife that finally they were forced to surrender." 251 Without a strong leader, democratic Athens was subject to the whims of those concerned with profit and gain. With no clear purpose other then that, the war that was caused by an earlier (perhaps better) kind of Athens overtook the Athenians of then. Donald Kagan argues that all of the conflicting personalities within Athens, coupled with "the panic of the demos," are what Thucydides describes as bringing the Athenian empire to its knees. ${ }^{252}$

Thucydides describes much of the internal strife as between oligarchic and democratic factions of Athens. As mentioned, because of the degradation of internal Athens, Athens ends up becoming overwhelmed by the effects of the war. In this regard the Athenian Assembly ends up submitting to the pressures of external

\footnotetext{
247 Thucydides, History of the Peloponnesian War, 164 (II 85)

248 Cohen, "Justice, Interest, and Political Deliberation in Thucydides," 51

249 Thucydides, History of the Peloponnesian War, 222 - 223 (III 49 - 50)

250 Thucydides, History of the Peloponnesian War, 539 (VIII)

251 Thucydides, History of the Peloponnesian War, 164 (II 85)

252 Kagan, The Great Dialogue, 107
} 
oligarchic factions and an oligarchic "Council of the Four Hundred" government is established in Athens. ${ }^{253}$ However, the factional conflict between the wealthy and the poor continues, "with the army trying to force a democracy upon the city, and the Four Hundred an oligarchy upon the army." ${ }^{254}$ In chaotic increments, the army of Athens, helped by fear of the Peloponnese at Athens' doorstep, forces the hand of the Council of the Four Hundred to vote in the Council of the Five Thousand.255 Thucydides describes this new government type as appearing to be "a better government than ever before, at least in my time."256 Perhaps it would not be safe to say Thucydides thought this as the ideal state, but he does write " $[t]$ here was a reasonable and moderate blending of the few and the many, and it was this, in the first place, that made it possible for the city to recover from the bad state into which her affairs had fallen." 257 Thucydides was as concerned about factional conflict between the wealthy and the poor causing political instability as Aristotle was in his Politics.

The degradation of morals and laws in the face of war, and human nature taking over the course of events, is argued to be one, if not the most important, of Thucydides' conclusions. "For Thucydides, in the end, human nature transcends national characteristics," Cohen writes. ${ }^{258}$ The conflict between democratic Athens and oligarchic Sparta causes this war that leads to degradation of morality. Thucydides points out that, as a result of the war, social bonds unravel, trust disappears, and humanity gives up to its baser nature. "Revenge was more important than self-preservation."259 Thucydides writes, along with passages such as "Love of power, operating through greed and through personal ambition, was the cause of all these evils....terrible indeed were the actions to which they committed

\footnotetext{
253 Thucydides, History of the Peloponnesian War, 576 (VIII 67)

254 Thucydides, History of the Peloponnesian War, 582 (VIII 76)

255 Thucydides, History of the Peloponnesian War, 597 - 598 (VIII 96 - 97)

256 Thucydides, History of the Peloponnesian War, 598 - 599 (VIII 97)

257 Thucydides, History of the Peloponnesian War, 599 (VIII 97)

258 Cohen, "Justice, Interest, and Political Deliberation in Thucydides," 42

259 Thucydides, History of the Peloponnesian War, 243 (III 82)
} 
themselves, and in taking revenge they went farther still."260 Perhaps the most prolific line is, "As a result of these revolutions, there was a general deterioration of character throughout the Greek world." 261 He writes that the first examples of the breakdown of law and order were in Corcyra, where there were,

“...the savage and pitiless actions into which men were carried not so much for the sake of gain [but] because they were swept away into internecine struggle by their ungovernable passions. Then, with the ordinary conventions of civilized life thrown into confusion, human nature, always ready to offend even where laws exist, showed itself proudly in its true colours, as something incapable of controlling passion, insubordinate to the idea of justice, the enemy to anything superior to itself...it is true that these acts of revenge on other men take it upon themselves to begin the process of repealing those general laws of humanity which are there to give a hope of salvation to all who are in distress, instead of leaving those laws in existence, remember that there may come a time when they, too, will be in danger and will need their protection."262

Thucydides also describes scenarios where temples are disrespected and violated, and moral traditions and taboos having to do with the treatment of the dead are broken. ${ }^{263}$ In this, warfare causes the cessation of morality and better aspects of human nature.

So because of poor judgment, lack of critical analysis, inability to stick with decisions, and self-interested individuals gaining power over the state, Athens ended up turning the Greek world against them. The war that was started in a more capable Athens ends up overwhelming Athenians as they fall under the pressures of

\footnotetext{
260 Thucydides, History of the Peloponnesian War, 243 (III 82)

261 Thucydides, History of the Peloponnesian War, 244 (III 83)

262 Thucydides, History of the Peloponnesian War, 245 (III 84)

263 Thucydides, History of the Peloponnesian War, 323 (IIIV 97)
} 
war. The literature upon Thucydides, very similar to Plato, is nearly endless in it's variety and complexity of interpretations and possible meanings. For the purposes of this paper, the basic contentions described above will stand.

With all three of these philosophers now described, let us look at their criticisms of democracy in sharper focus and build a synthesis of classical political theory that can be utilized for application to modern day democracy. 


\section{SECTION TWO: Classical Theory on Democracy in General}

This section will be dedicated to forming a coherent and applicable synthesis of all three of these philosophers' theories on democracy. Remaining within the above format, the similarities and differences between these philosophers will be compared and contrasted in order to form a streamlined theory of description, cause, and effect of democracy.

\section{Description}

Plato and Aristotle both agree that democracy is a regime built on equality for all, with the power in the hands all, which for all intents and purposes meant the poor. Citizens have all equal rights by birth, and are characterized by extreme liberty. As should be obvious at this point, they did not think this was a good thing. Being misanthropic, they were highly suspicious of natural goodness within people, and saw democracy, with its extreme liberty and intolerance of rules, as having no safeguards against the worst aspects of human behavior. Aristotle is more tolerant of democracy because of his thesis of making every regime the best possible. However, his writings are based on the idea that those reading his works are attempting to better the regime, so the focus causes differences. In contrast, Plato's distaste is fairly obvious. Plato's description of the excessiveness of liberty in democracy seems exaggerated, but the main gist is that it is liberty to the point of arrogance and rudeness. Aristotle describes it as equality for equality's sake.

Their pivotal problem with democracy is that they believe it has no inherent moral virtue. The consensus seems to be that without moral virtue, they believe democratic citizens will be defenseless against resisting unhealthy desires, as well as not understanding the difference between right and wrong. Again, this is because of their distrust of human nature, which is exacerbated by democratic regimes not requiring moral education.

Without this moral education, Aristotle and Plato regard democratic citizens as easily manipulated and prone to flights of fancy, as well as very susceptible to falling under bad influences. This makes them highly subject to rhetoric and 
rhetoricians - though Plato speaks more about this than Aristotle. Thucydides describes poor judgment and fact gathering on the part of the democratic Athenians. It is also of interest that Thucydides describes Athens at first as being moderate in contrast to Plato and Aristotle's description of democracy as being prone to whims and flights of fancy. However, that seems more to do with the time period that Pericles was a leader, and Thucydides later does describe very impulsive and indecisive decisions on the part of the Athenians when other generals have control. Again this returns to democracy having no safeguards against the negative aspects of human nature, as unfit individuals are able to take hold of the state. As a final note, they believe that without education there is also no intellectual virtue. Considering Plato and Aristotle see this as the means to supreme happiness, this indicates that in their minds democracies are inevitably unhappy. Aristotle also believes democracy exists without real friendship, only existing in a state of superficial relationships.

Plato, Aristotle, and Thucydides all describe democracies as having factional conflicts between the wealthy and the poor in some form or another. Plato's transition from oligarchy to democracy involves these factors, and the continual conflict between the wealthy and the poor leads to the tyrannical rule that is his ultimate conclusion. Aristotle is more straightforward about it, stating that it is the faction to fight most often, as well as relating the continual revolutions between democracy and oligarchy. In Thucydides' History, the war is of course between oligarchic and democratic factions. Thucydides also describes, towards the end of his History, the Athenian government flipping back and forth between the wealthy and the poor gaining control. Aristotle and Thucydides could be considered as mirroring each other in describing the continual revolutions between the two; Aristotle speaks directly from theoretical while Thucydides explains it through example.

Thucydides also describes Athens as very self-interested. This seems relatable to the other two in the regard that selflessness is more associated with virtues and altruism, which Plato and Aristotle do not see as being part of democratic society. It could be said that Plato sees the excessive liberty of 
democratic citizens as all about self-interest; with no real concern with others, they are arrogant and rude. Aristotle does not have much to say about the tie between democracy and self-interest, but the concern with states having virtue still stands. Thucydides also describes Athens as not being very interested in conceptions of justice or morality, which is obviously an instant problem for Plato and Aristotle. Self-interest can also be seen as connected to the desire for self-profit, which is the beginning of the downfall for Plato's evolution into tyranny and Aristotle's transition into oligarchy.

\section{Causes and Conditions}

Both Plato and Aristotle describe democracy as coming about through revolutions. Both describe this as occurring in reaction to an oligarchic regime, which fits into their conception of factional fighting between the wealthy and the poor. It is also important to note that Thucydides describes Attica, or pre-Athens, as developing relatively protected from conquest because its poor soils were not valuable, which allowed it to evolve fairly free from subjugation. Perhaps this is how the spirit of freedom and independence was cultured in this society.

Thucydides' recounts conflict encompassing the development of Athens, and thus has a culture of war and an abundance of military experience as part of the democratic state. The literal reality of Athens' growth of empire has to do with its relative strength during the Persian War, as other countries fled to Athens for aid and alliance in order to be protected. However, this dynamic changes as Athens refuses to give up this empire when the Persian War was over for fear of Sparta gaining strength. Thucydides also has Athens as describing its rise to power - and its refusal to give up this power - through the ideological concepts of honor, interest, and security.

Aristotle also believes that democracies arise during growth of populations. Plato does not seem to have much of a description about population densities in relation to constitutions. Thucydides, however, describes that Attica became Athens through the influx of refugees from surrounding areas that were torn by war and 
conflict. It even had to create colonies outside of the city limits because of population size; of course, adding more democratic regimes to the area.

Thucydides also focuses on the concept that different kinds of individuals create various kinds of democratic national identities. In this regard the character of people becomes the character of the state. This replicates the earlier assertion of this paper that because democracy is a reflection of its citizenry, democracy will ultimately exacerbate whatever characteristics the people hold; but perhaps this argument needs to be specified into democracy exacerbating whatever characteristics those in government hold, instead of the citizenry as a whole. After all, the difference of individuals like Pericles and Cleon ultimately changed the shape of how Athens as a democracy acted. Ultimately this can be considered on the same level as Plato and Aristotle's concern for the extreme susceptibility of democracy to tyranny, otherwise known as the whims of leaders.

In concluding this section upon causes and conditions, it seems prudent to discuss Aristotle's notions on revolution and change, both in general and specifically to democracy. As mentioned before, Aristotle writes that in revolutions people aim for equality or superiority, a common sense conclusion. Also recall Aristotle's hypothesis that conflict is engaged in because of profit, honor, or avoidance of punishment. The general factors that Aristotle describes in bringing about revolutions are fear, superiority, contempt, disproportionate growth of a part, electioneering, neglect of small things, and dissimilarity. It at first seems obvious that electioneering, or campaigning, is something that is intrinsically going to be involved in democratic states; in order to be elected, an individual must make him or herself known, to address issues and make promises, in order to garner support. It would seem plausible to jump to the conclusion that Aristotle cautions against this method because of his concern over tyranny. After all, if someone is very good at speeches and campaigning, perhaps this individual would also lie or manipulate in order to achieve office for self-gain. This seems to be involved in the subject of rhetoric. In manipulating the citizenry, if this individual has a gift for it, what is to stop this individual from achieving office and becoming a tyrant? Perhaps that is the warning that needs to be taken from his cautioning against 'electioneering.' 
For factors specific to democracy, Aristotle wrote that it forms because of wanton behavior of popular leaders. This is seen in either harassment of property owners to the point of an alliance being formed against the leaders, or because popular leaders end up provoking the majority into revolting. If this alliance of property owners had its way, this would most likely end up as a change to an oligarchy, which is what Aristotle is probably leading to. Provoking the majority into revolting would probably end up with either a part changing via revolution, or a change to a more-democratic overall.

\section{Effects and Lessons}

The most obvious effect that these three philosophers relate is how prone democratic citizens are to making bad decisions. Through poor understanding of right and wrong, poor judgment of facts and people, and poor education, democracies are highly susceptible to error. In this regard all three philosophers also seem to be saying they believe democracy will inevitable be taken over by corrupt leaders, through the power of rhetoric and the influence of greed. Plato and Aristotle focus more heavily on the idea that lack of virtue leads to the corrupting influence of wealth gaining hold. Thucydides sees this more as wealth corrupts the state when virtuous people are not in control (or have a lot of influence). Plato would heartily agree with this statement, for as we already covered, he believed that only virtuous people should be in charge and that the interest for self-profit would inevitably bring the destruction of the ideal. Plato also describes that if there are those who are virtuous within a democracy and who try to teach others to be virtuous, they will be ridiculed and possibly condemned to trial.

All three philosophers say (or imply) that these corrupt leaders will cause a transformation of the state into something other than a democracy. Plato focuses on tyranny as the main conclusion of this evolution (either in the form of a tyrant or in the form of the majority), though Aristotle and Thucydides see oligarchy as the more plausible option. They all seem to be saying that the conclusion of democracy is the end of democracy. 
Thucydides shows that democratic and pugnacious Athens engaged in too many wars, overestimated its capabilities and power, and ends up causing the destruction of the altruistic parts of human nature and the creation of something akin to chaos. The Athenian empire becomes oppressive, some would say tyrannical. In fact Cleon, who takes control over Athens for a while, defines Athens as a tyranny. The lack of protections against non-virtuous leaders causes a lack of direction and purpose as individual fight for power for themselves, causing this overextension in international affairs.

Now equipped with an understanding of these philosophers, the conclusion is a desperate need for education. As already described, Plato and Aristotle articulate a detailed education system that is catered towards teaching people how to think and generating virtue. Not all of this is generated through instruction because habits learned through practice and growing up is an important aspect as well; this implies that parents or guardians must be virtuous in order to raise a virtuous next generation. While Plato is a bit hierarchical in setting up a system of tests where only the proficient end up continuing on, Aristotle focuses on the fact that all (being men, of course) should have education to create both community and better virtue in all. Aristotle's version of education seems more applicable in the context of democracy (including women, of course), for under democratic ideology all should have equal excess to education and the ability to better oneself. Plato counters this by describing the danger of those who are smart but not virtuous using this education for negative ends. Adolf Hitler seems to be the obvious contemporary example. However, Aristotle's counter seems to be that the more education the populous has, the less likely they are to fall under the whims of manipulation or rhetoric. But in a state that is based on choice, unequal levels of education causing some to have more power over others is a legitimate danger. And if those with more education have less virtue, Plato's warning of rhetoric falling into the hands of the bad spells the danger of tyranny he has been touting all along. A prevention of Plato's evolution into tyranny requires a constant attention to education, as well as a continual attention to facts and critical thinking that Thucydides describes as a weak point within democracy. 
This attention to facts and critical thinking is interconnected with education, but it is also important to remember news and media involvement. Concerns over media made in correlation with democracy only existing with a well-informed public has been an issue echoed almost constantly through democratic history. Aristotle also had several requirements he believed would help a regime survive. The general, in summary, were having a strong middle class, intolerance of the transgression of laws, creating no laws against the majority of people, always treating citizens with kindness and respect, the citizenry understanding how the regime could fall, guarding against factional conflict, and have short office terms so that individuals did not have power for long periods of time. These will resonate in most democratic citizens, some of the requirements more so than others.

A table organizing this data has been provided below. 


\section{Data Organization Table for Section Two: Classical Theory on Democracy in General}

\begin{tabular}{|c|c|c|c|}
\hline & Plato & Aristotle & Thucydides \\
\hline Description of democracy & $\begin{array}{l}\text { Excess of liberty; } \\
\text { Lack of moral } \\
\text { virtue and } \\
\text { education; Easily } \\
\text { manipulated; } \\
\text { Factional conflict } \\
\text { between wealthy } \\
\text { and poor }\end{array}$ & $\begin{array}{l}\text { Equality for } \\
\text { equality's sake; } \\
\text { Lack of moral } \\
\text { virtue and } \\
\text { education; Easily } \\
\text { manipulated; } \\
\text { Factional conflict } \\
\text { between wealthy } \\
\text { and poor } \\
\end{array}$ & $\begin{array}{l}\text { Bad decision } \\
\text { makers; Poor } \\
\text { judgment; } \\
\text { Factional conflict } \\
\text { between wealthy } \\
\text { and poor; Self- } \\
\text { Interested }\end{array}$ \\
\hline Causes and conditions & $\begin{array}{l}\text { Creation via } \\
\text { revolution; highly } \\
\text { susceptible to } \\
\text { being taken over } \\
\text { by the self- } \\
\text { interested }\end{array}$ & $\begin{array}{l}\text { Creation via } \\
\text { revolution; due to } \\
\text { growth in } \\
\text { populations; highly } \\
\text { susceptible to } \\
\text { being taken over by } \\
\text { the self-interested }\end{array}$ & $\begin{array}{l}\text { Relatively } \\
\text { protected from } \\
\text { conquest; culture } \\
\text { of war; empire } \\
\text { built through } \\
\text { alliances; grew to } \\
\text { strength through } \\
\text { honor, interest } \\
\text { and fear; different } \\
\text { individuals create } \\
\text { different national } \\
\text { characteristics }\end{array}$ \\
\hline Main effects and lessons & $\begin{array}{l}\text { Extreme error in } \\
\text { decisions; will } \\
\text { turn into tyranny, } \\
\text { either of an } \\
\text { individual or the } \\
\text { majority; needs } \\
\text { quality, rigorous } \\
\text { education and } \\
\text { media }\end{array}$ & $\begin{array}{l}\text { Extreme error in } \\
\text { decisions; will most } \\
\text { likely turn into an } \\
\text { oligarchy (and back } \\
\text { again); needs } \\
\text { quality, rigorous } \\
\text { education and } \\
\text { media; needs } \\
\text { factors described } \\
\text { just above to } \\
\text { prevent revolution }\end{array}$ & $\begin{array}{l}\text { Extreme error in } \\
\text { decisions; engages } \\
\text { in too many wars, } \\
\text { overextends } \\
\text { power, becoming } \\
\text { oppressive; } \\
\text { confusion in } \\
\text { direction of policy }\end{array}$ \\
\hline
\end{tabular}




\section{SECTION THREE: The Importance to American Democracy}

Before delving directly into the comparisons between ancient political theories and current trends in modern America, we must pause and address a few factors. First it is important to note that the United States was created in the terms of a "Republic," and even though it has since shifted to have more democratic structures, there are still themes in American governing which muddle the definition of the regime even to contemporary standards. In fact, Ido Oren, in his book Our Enemies and US, not only outlines the way in which American definitions of political science have changed over the past centuries depending on the particular war the United States was engaged in, but also describes how definitions of democracy have changed along with it. ${ }^{264}$ In this regard it must be kept in mind that concepts such as "democracy" are fluid and evolving.

It is also of interest to note that ideas similar to these philosophers, specifically their concerns with tyranny, influenced the creation of the American government. Several scholars have described the many ways in which the framers of the United States constitution were quite aware and explicit in their understanding and use of classical critiques of democracy in the creation of American government by "rule by the people." $265 \mathrm{~A}$ worry over the rise of individual tyrants can be seen in the separation of the legislative and executive branches. This structure has often been criticized for causing inefficiency in management and governing - as can be seen in current stalemates and stonewalling between Congress and President

\footnotetext{
264 Ido Oren, Our Enemies and US, (Ithaca: Cornell University Press, 2002); a great (and relatively quick) understanding of this argument can be gleaned from Oren's introduction.

265 Michael D. Chan, Aristotle and Hamilton on Commerce and Statesmanship (Columbia: University of Missouri Press, 2006); Michael P. Zuckert, et al. Thomas Jefferson and the Politics of Nature, ed. Thomas S. Engeman (Notre Dame: University of Notre Dame Press, 2000), Garrett Sheldon's piece in particular mentions Aristotle, but themes can be found throughout the works; Andreas Kalyvas, "The Tyranny of Dictatorship: When the Greek Tyrant Met the Roman Dictator" Political Theory 35 (Aug. 2007): 412 - 442; James W. Ceaser "Demagoguery, Statesmanship, and the American Presidency," Critical Review: A Journal of Politics and Society 19, (2007): 257-298
} 
Obama - but is a defense nonetheless. The short lengths of terms are also safeguards against this issue. Concerns over the tyranny of the majority can be seen in the structuring of the Senate and the House of Representatives: with the Senate's equal representation of States regardless of population, the interests of less-populous states are protected against more populous majorities. In this context modern day United States can be seen as a continuing evolution of an attempt to safeguard democracy against concerns of tyranny.

\section{Description}

For this section this paper will be looking at what Plato, Aristotle and Thucydides see as the defining features of democracy. These include issues such as equality based on birth, power in the hands of the poor, liberty to the point of arrogance and rudeness, lack of moral virtue, poor education, citizens being easily manipulated and prone to rhetoricians, citizens being ultimately unhappy, and the national characteristic of self-interest. These descriptions of democracy will be compared to trends in the United States below.

Plato and Aristotle's description that democracy is rule by the many poor with an ideology of equality for all definitely fits in theory. That is what the United States is supposed to be built on; all individuals having a right to engage in the governing process. Whether it is by voting, running for political office, or deciding to not engage in politics - the point is that the citizens all have a choice and the right to be involved. Yet an interesting conundrum arises when looking at this in practice. First off, it is also a known fact that those who are wealthier and better educated are more likely to engage in politics, which inadvertently causes a bias both on the side of those running for office as well as those voting. It is also known fact that running for a political office requires money - lots of it. ${ }^{266}$ This suggests that candidates must have money in order to participate directly in governing, which is starting to sound suspiciously like oligarchy. In counter, there are laws in place that prevent a

\footnotetext{
266 According to opensecrets.org, in the last (2012) election, President Obama spent $\$ 1,107,029,174$ total; $\$ 683,546,548$ as a candidate, $\$ 292,264,802$ from his party, and $\$ 131,217,824$ in outside spending. Mitt Romney spent $\$ 1,238,072,571$ total; $\$ 433,281,516$ as a candidate, $\$ 386,180,565$ from his party, and $\$ 418,610,490$ from outside spending. <http://www.opensecrets.org/pres12/>
} 
candidate from using a vast amount of his or her own money in order to campaign for election, so in theory, those born to wealth do not have an automatic ability to campaign and engage in office. Campaign funds come from donors, contributions running from common citizens who contribute a few hundred at the highest to Super PACS that contribute sometimes up to millions. The ability to attract donors is supposed to be based on merit and ability of the politician to champion causes that people are most concerned about. Yet this is first complicated by concerns with pleasing high-income donors, the agendas of Super PACS, and a politician's party, in order to gain the money needed in order to run. Going even further, Nicholas Carnes illustrates in his thesis dissertation "By the Upper Class, for the Upper Class? Representational Inequality and Economic Policymaking in the United States," that there is a high inequality of representation of income groups in United States government. Nearly all presidents within the last century have come from wealth, the current supreme court has a 5-4 majority of millionaires, Congress is "composed overwhelming" of the wealthy, and while several justices grew up in families of "arguably" moderate means, only two came from blue-collar families. ${ }^{267}$ In the end, the general trend still seem to be that politicians, specifically those in more powerful offices, come from wealth.

Yet even if a huge majority of politicians are wealthy, does this mean that they only represent the views of the wealthy? Intuitively it might seem that like would cater to like. In Larry Bartel's article "Economic Inequality and Political Representation" he finds in his data that Senators are 50\% more responsive to rich constituents on key political issues than to those with more modest means. He even states that the views of constituents on the bottom third of the income distribution received "no weight at all in the voting decisions of their senators." 268 In contrast, there was a recent study done in 2011 by economists Eric Brunner, Stephen Ross, and Ebonya Washington who find that the data on representation by income is

\footnotetext{
267 Nicholas Carnes, "By the Upper Class, for the Upper Class? Representational Inequality and Economic Policymaking in the United States" (PhD diss., Princeton University, 2011), 5 - 7 268 Larry Bartel, "Income Inequality and Political Representation," in the Princeton University database for Bartel's working papers, http://www.princeton.edu/ bartels/economic.pdf, written August 2005
} 
actually ambiguous. The only variable that makes a difference upon voting trends is the ideological standpoint of the wealthy, but that the difference between the wealthy and the poor is smaller than assumed. ${ }^{269}$ However, this study was only done in the confines of the state of California; further study would need to be done in order to see if this was a tendency on a national scale. In rebuff, Martin Gilens in Affluence and Influence compiles a dataset of survey questions reflecting the policy preferences of United States citizens at different income levels. Compared to actual policy decisions made by legislators and the President, Gilens' data shows a strong tilt in responsiveness towards the most affluent citizens. ${ }^{270}$ Gilens also details in chapter 8 of this book that as economic inequality has been increasing in the United States for about the past three decades, responsiveness to the more "affluent" in American society has also grown. ${ }^{271}$ An extraordinary amount of money needed to gain political office, a highly unequal ratio of wealthy to poor in political office, a bias in representation towards those who are more affluent, and an increase of responsiveness towards those who are so; it all begins to paint a picture of something more like the ancient definition of oligarchy. Yet let us move on from this for now and address the other factors that the three philosophers describe as definitions of democracy.

Next on the list, Plato's perceives democratic citizens having an "excess of liberty" and intolerance to rules to the point of arrogance and rudeness. This is a tricky subject to broach. On the one hand American tourists are often considered obnoxious or frustrating when they are abroad, and there is a common arrogance about being "the best" that can be seen in most forums of American media and ideology. Yet this view should be tempered by understanding that most citizens, of any country in good conditions, are going to see attributes of their state as being better than nations abroad. It would seem, however, that the United States has a particular excessiveness in this area. On the subject of rules, it certainly seems as

\footnotetext{
${ }^{269}$ Eric Brunner, Stephen Ross, and Ebonya Washington, "Does Less Income Mean Less Representation?" National Bureau of Economic Research Working Paper Series Paper No.: 16835 (Feb. 2011; Revised Jan. 2012)

270 Martin Gilens, Affluence and Influence, (Princeton: Princeton University Press, 2012): 1

271 Gilens, Affluence and Influence, $234-252$
} 
though there is a lot of intolerance on the behalf of citizens to government oversight. Animosity towards government regulation is a constant message in American social media. This could be countered by saying, in the interest of making sure tyranny does not develop within the United States, scrutiny of government regulations and procedures in a must. On this subject it is a toss-up.

Addressing Plato and Aristotle's claim that democracy lacks in moral virtue is also tricky. It is a normative analysis and is by definition difficult to quantify. There is, however, one way to attempt to quantify some part of this discussion of morality. After all, crimes such as murder, rape, theft, and destruction of property are pretty much universally considered immoral. It would seem relevant here to cite the per capita incarceration rate of United States citizens, for the United States incarcerates more people per capita than any other country in the world, at about 743 per every 100,000.272 The Bureau of Justice has this number for 2011 at "about 1 in every 50 adults in the U.S. was supervised in the community on probation or parole while about 1 in every 107 adults was incarcerated in prison or jail."273 Also fascinating to realize is the United States ratio of incarcerated citizens to total world population. According to the Census Bureau, the United States population for April 2013 was $315,927,890 .{ }^{274}$ In addition, the Census Bureau has the world population, midyear of 2013, at 7,095,217,980.275 This adds up to the United States holding about $4.5 \%$ of the world's population. Holding 2,239,800 incarcerated citizens, compared to the world's 10.1 million incarcerated citizens, the United States has about $22 \%$ of the

\footnotetext{
272 International Center for Prison Studies. World Prison Population List, $9^{\text {th }}$ edition (May 2011), by Roy Walmsley. Report. Last accessed May 30, 2013. <http://www.prisonstudies.org/images/news_events/wppl9.pdf>

273 U.S. Department of Justice. Office of Justice Programs. Bureau of Justice Statistics. "Correctional Populations in the United States, 2011" (November 2012) by Lauren E. Glaze and Erika Parks. <http://www.bjs.gov/index.cfm?ty=pbdetail\&iid=4537>

274 U.S. Census Bureau, Population Division, "Table 1. Monthly Population Estimates for the United States: April 1, 2010 to April 1, 2013 (NA-EST2012-01-413)" Released May 2013.

275 U.S. Census Bureau. "International Programs; Total Midyear Population for the World: 1950 2050," Last accessed May 21, 2013.

<http://www.census.gov/population/international/data/idb/worldpoptotal.php>
} 
world's incarcerated citizens. ${ }^{276}$ This concludes with the United States having 22\% of the world's imprisoned citizens with $4.5 \%$ of the total world population.

However, this data can be subjective, as each country has varied approaches to the criminal justice system and what crimes they incarcerate citizens for. Perhaps a better way to understand lack of morality on this basis would be to look at crime rates instead of incarceration rates. In this regard it seems appropriate to look at homicide rates cross-nationally. According to the most recent homicide statistics put out by the United Nations Office on Drugs and Crime, the United States homicide rate was 4.8 in 2011. This is compared to similar countries such as Great Britain at 1.2, France at 1.1, Finland at 2.2, Russia at 10.2, Sweden at 1.0, China at 1.0, Australia at 1.0 , Spain at 0.8, Germany at 0.8 , and Singapore at 0.3 . The highest rates of homicide appear in places such as Southern Africa with Lesotho at 35.2 and South Africa at 31.8; the Caribbean with Jamaica at 40.9 and Saint Kitts and Nevis at 38.2; Central America with Honduras at 91.6 and El Salvador at 69.2; and with others I will not go into here. Considering that nations with more democratic elements have some of the lowest homicide rates, the statistics do not seem to show a correlation between democracy and higher rates of homicide. There must be factors involved here. Using homicide rates as a judge of morality, these philosophers are not proven correct.

Continuing on, while Plato and Aristotle's conception of morality is broadly the ability to tell the difference between right and wrong, they more specifically state it as living a life of philosophy and intellectualism as well as resisting unhealthy desires. To delve into this as the basis for morality, living an intellectual lifestyle to consider the broader meanings of life is not something that every one of us can afford, both in the ability to pay for that leisure as well as dedicate that much time. The discipline of philosophy itself is far from a flourishing field in modern day America. In a more contemporary view, a life of intellectualism could be interpreted as scholars who are dedicated to research. However, Plato and Aristotle's intellectual virtue is not so much about physical reality so much as what they deem

276 U.S. Department of Justice. Bureau of Justice Statistics. "Correctional Populations in the United States, 2011"; International Center for Prison Studies. World Prison Population List, $9^{\text {th }}$ edition 
as truths and wisdom. The first part of Plato and Aristotle's conception of morality, a life of philosophy and intellectualism, it would be safe to say is not a flourishing part of American democratic society. It can be argued that contemporary standards have changed what value is placed on certain disciplines, that modern times call for modern issues and concerns. But in this way, Plato and Aristotle's issue with democracy still stands.

In using the concept of resisting unhealthy desires as a basis for judging morality, two subjects can be brought to attention: America's obesity problem and addiction problem. This paper will be considering both obesity and addiction in the context of Plato and Aristotle's "unhealthy desires" because they are, by definition, both unhealthy and related directly to their conceptions of "appetite." Plato even mentions overeating in his discussion of unhealthy desires. In the interest of being sensitive, it is true in modern times that some obesity is considered a disease, and there are medical problems that lead to excessive weight gain that are legitimate medical conditions to be treated. However, it almost goes without saying that the poor diet decisions of United States citizens also contribute the overweight problem. In the context of addictions it is also true that many of them are problems that require medical treatment or rehabilitation. Yet according to several studies published in the American Journal of Psychiatry, 48\% - 58\% of a person's susceptibility to alcohol addiction is based off of genetic factors, while the rest is based off of what could be considered poor coping skills. ${ }^{277}$ It could be argued that because of a lack of practiced good habits and instilled moral teachings (what these philosophers believe), individuals are more prone to addictions and "unhealthy desires" within a democratic state. It seems reasonable to at least look at the problems of obesity and addiction as interconnected with Plato and Aristotle's theories.

277 Carol A. Prescott, Ph.D. and Kenneth S. Kendler, M.D. "Genetic and Environmental Contributions to Alcohol Abuse and Dependence in a Population-Based Sample of Male Twins." American Journal of Psychiatry 156 (1999): 34 - 40; the online article version also has links to several other studies done with similar results. <http://ajp.psychiatryonline.org/article.aspx?articleID=173214> 
First, in addressing obesity, the Centers for Disease Control and Prevention has $35.7 \%$ of adults in the United States as considered obese. ${ }^{278}$ The Central Intelligence Agency has a report for a 2012 feature story that shows the United States as sixth most obese country in the world, behind American Samoa, Tokelau, Tonga, Kiribati, and Saudi Arabia. ${ }^{279}$

Second, in turning to addictions, the Institute of Addiction Medicine has "Americans, who represent less than 5\% of the world's population, are by far the largest group of opioid users; $80 \%$ of the world's supply of opioids (and $99 \%$ of the hydrocodone available globally) are used by people in the United States." 280 The 2011 National Survey on Drug Use and Health has 8.7\% of those 12 years or older using illicit drugs in the past month, with the rate of marijuana use increasing over the past decade along with other drugs either maintaining a steady level of use or decreasing slightly. ${ }^{281}$ The World Drug Report has the United States in the year 2010 as one of the nations with the highest use of drugs such as cannabis, amphetamine-type drugs, opioids, cocaine, ecstasy, and to a slightly lesser degree, opiates. The United States is joined by Australia, Britain, Spain, parts of the Middle East, and southern parts of Africa as the nations with the highest use of some of these drugs. ${ }^{282}$ All of this data leads to a fairly grime picture of American citizens' use and abuse of "unhealthy appetites." The raw data, at the very least, seems to be tending towards proving correct Plato and Aristotle's impression of United States democratic citizens as being highly susceptible to unhealthy desires. Though it is important to note that other democratic nations do not join the United States in across-the-board high drug use, or the highest obesity rates. While the United States

\footnotetext{
278 Centers for Disease Control and Prevention. "Overweight and Obesity." Page last updated August 13 th 2012. Last accessed May 16, 2013. <http://www.cdc.gov/obesity/data/adult.html>

279 Central Intelligence Agency. "A Spotlight on World Obesity Rates." Last updated November $20^{\text {th }}$ 2012. Last accessed May 16, 2013. <https://www.cia.gov/news-information/featured-storyarchive/2012-featured-story-archive/obesity-according-to-the-world-factbook.html> 280 Institute for Addiction Medicine. "Statistics." < http://www.ioam.org/statistics.html> 281 The Substance Abuse and Mental Health Services Administration. "2011 National Survey on Drug Use and Health." Last accessed May 16, 2013. <http://www.samhsa.gov/data/nsduh/2k11results/nsduhresults2011.htm\#Ch2> 282 United Nations Office on Drugs and Crime. World Drug Report 2012 (United Nations publication, Sales No. E.12.XI.1) Last accessed May 16, 2013. Pgs. 8 - 12 <http://www.unodc.org/documents/data-and-analysis/WDR2012/WDR_2012_web_small.pdf>
} 
seems to be in line with these philosophers' theories on this level, a more detailed analysis of other democratic nations would behoove this direct theory application.

Next, Plato and Aristotle focus on the fact that those who are morally excellent are brought up with good habits as well as rigorously trained and educated. There is of course contention in the definition of "morally excellent" as well as "good habits," and endless arguments on how to raise children with good habits and morals. However, the question of education within America is something that can be addressed. ${ }^{283}$ It is generally known fact that the United States education system lags behind other industrialized or industrializing nations according to international testing scores. In the 2011 "Progress in International Reading Literacy Study," (the last year with published reading scores so far) with 57 countries participating, the U.S. was in the top 13 countries for average fourth grade reading scores, with 5 countries averaging higher and 7 countries averaging about equal. ${ }^{284}$ For the 2011 "Trends in International Mathematics and Science Study," also with 57 countries participating, the U.S. was in the top 15 for average fourth grade math scores, with 8 countries averaging higher and 6 countries averaging about the same. For $8^{\text {th }}$ grade math, the U.S. was in the top 24 with 11 higher and 12 about the same. ${ }^{285}$ For science, also tested in the TIMSS, the United States was among the top 10 for fourth grade, with 6 countries higher and 3 about the same, and the top 23 for eighth grade, with 12 countries higher and 10 about the same. ${ }^{286}$ Although this does not look bad upon a global scale, it's puzzling to see that as grade level rises, scores relative to other nations decrease. Does this mean that as United States children get

\footnotetext{
283 Allan David Bloom, The Closing of the American Mind: how higher education has failed democracy and impoverished the souls of today's students (New York: Simon and Schuster, 1987); here, Bloom actually argues that the "social and political crisis of the $20^{\text {th }}$ century" is actually an intellectual crisis because of the decline in the appreciation of the humanities, a drop in qualitative focus in universities, and a disconnect between students and their spiritual and cultural heritage. This seems to be very much in line with what these philosophers articulate in their theories, and I thought it worth mentioning.

284 National Center for Education Statistics, "PIRLS 2011 Results,"

<http://nces.ed.gov/surveys/pirls/pirls2011.asp>

285 National Center for Education Statistics, "Mathematics Achievement of Fourth- and EighthGraders in 2011," <http://nces.ed.gov/timss/results11_math11.asp>

286 National Center for Education Statistics, "Science Achievement of Fourth- and Eighth-Graders in 2011," <http://nces.ed.gov/timss/results11_science11.asp>
} 
older, they are getting relatively less smart? Or are other countries the opposite, getting relatively smarter as they grow older?

Besides, what does this ranking mean? Does this disprove or prove Plato and Aristotle's theory of lack of education within America when the United States ranks high compared to the rest of the world but about "middle of the pack" with comparable industrialized nations? This is somewhat difficult to interpret because many of the countries comparable to the United States could also be considered democratic, and comparing democracy to democracy would seem to be useless for interpreting these philosopher's theories. It is significant to note that Hong Kong, which is not democratic in nature, consistently scores at the top because of its rigorous education system. ${ }^{287}$ It is also fascinating to realize that Singapore, another country that consistently scores high, has a "streaming" or "tracking" education system that places students in particular areas of education and training depending on certain tests, focusing education on each student's individual capability and talent. ${ }^{288}$ There is a striking similarity here to Plato's description of his ideal education system. It is also important to note that both Singapore, and Finland, another high ranker, highly emphasize education-for-all. Finland specifically focuses on all students being taught in the same common school system, highly emphasizes parent involvement, and requires students to be independent in their own education from an early age. ${ }^{289}$ This is very similar to what Aristotle describes in his ideal education system.

Another issue with American education lies in what is called the "Achievement Gap," of the disparity in education level between white citizens and

287 Center on International Education Benchmarks, "Hong Kong: Instructional Systems," Last accessed June 6, 2013 <http://www.ncee.org/programs-affiliates/center-on-internationaleducation-benchmarking/top-performing-countries/hong-kong-overview/hong-kong-instructionalsystems/>

288 Center on International Education Benchmarks, “Singapore: Overview," Last accessed June 6, 2013. http://www.ncee.org/programs-affiliates/center-on-international-educationbenchmarking/top-performing-countries/singapore-overview/

289 Center on International Education Benchmarks, "Finland: System and School Organization," Last accessed June 6, 2013. http://www.ncee.org/programs-affiliates/center-on-international-educationbenchmarking/top-performing-countries/finland-overview/finland-system-and-schoolorganization/ 
ethnic minorities. Many scholars over the years have studied and raised concerns about the inequality in education between white, more privileged Americans and ethnic or racial minorities. Often this problem has been attributed to segregation of certain poor-achieving schools that are often highly concentrated in minorities. ${ }^{290}$ However, the general consensus arises that it is not just the education system itself that causes this inequality, but an overall culmination of factors, including historical, economic, sociopolitical, and moral. ${ }^{291}$ It is interesting to note that in places such as Hong Kong, Singapore, and Finland, parental involvement is highly required and seemingly part of the culture itself. ${ }^{292}$ Education inequality may be less about the education system and more about the whole cultural construct of education itself.

Perhaps this inequality of education would not be as bad as it seems in Plato's eyes; after all, he believes that each individual has his or her own particular talents, and this may not include "book smarts" in our conventional sense. Perhaps their talents lie elsewhere, and would be better used in other markets (and maybe even happier there). Aristotle, and most likely Thucydides, would deem this inequality as bad as it inevitably leads to some citizens having more power over others. This inequality gap is also a symptom of oligarchy.

It is a strange correlation to see the very rigorous and test-score-focused Hong Kong education system achieving the same high results as Finland, which only has periodic exams of a sample of students in grades 6 and 9.293 Also very interesting to note is that both Singapore and Finland have very democratic or republic elements in their government. This seems to imply that Plato and Aristotle's theory that democracy lacks in education is much less accurate than their more specific theories on education. The important thing to take away from this, however, is that the United States has neither the very rigorous education system of Hong Kong nor the nationally important, individual-focused systems of Singapore

\footnotetext{
290 Gary Orfield and Chungmei Lee, "Why Segretation Matters: Poverty and Educational Inequality," Harvard University, The Civil Rights Project (Jan. 2005)

291 Gloria Ladson-Billings, "From the Achievement Gap to the Education Debt: Understanding Achievement in U.S. Schools," Educational Researcher 35 (Oct. 2006): 3 - 12

292 Center on International Education Benchmarks, "Hong Kong: Instructional Systems,"; "Singapore: Overview,"; "Finland: System and School Organization,"

293 Center on International Education Benchmarks, “Finland: System and School Organization,"
} 
and Finland. Thus, the United States lacks the ideal in education that Plato and Aristotle emphasize. It is also important to note that this is a somewhat unfair comparison; the United States population is massive compared to Singapore and Finland, who have much greater ease forming and changing their education systems. Aristotle's theory of democracies having higher populations comes to mind again; this paper does not have this focus, but it would be interesting to see if the smaller populations of states such as these would lend themselves to Aristotle's definitions of a polity: rule by the many virtuous. While Plato and Aristotle's high criticism of democratic education may be a bit misplaced, their specific theories on education seem to be holding strong. Focusing back on the United States, while it does not prove these philosophers right, it is far from proving them wrong.

For the next descriptive factor, in these philosopher's minds lack of education leads to lack of information, which leads to bad decisions and being easily manipulated. On a similar note, Anthony Downs writes in his book An Economic Theory of Democracy, that in a perfect world of perfect information, the electorate would vote rationally and within their own interests, ${ }^{294}$ and both the citizenry and government have a cyclical relationship of interdependence. ${ }^{295}$ Downs writes that the problem arises when the electorate does not have perfect information and is uncertain about policies or decisions. He writes that this causes those who lack information to have a high susceptibility of being persuaded by those who have more information, because ultimately those who have more knowledge will give a stilted view in the hopes to produce a decision that aids their cause. ${ }^{296}$ He even goes so far to say that the persuasion or manipulation of voters is a rational action on the government's part, economically speaking. He also reinforces the earlier concept that the government holds some voters in higher esteem rather than others, not specified to wealth but rather that it is rational because some voters have more

\footnotetext{
294 Anthony Downs, An Economic Theory of Democracy (New York: Harper and Brothers, 1957), 49 50

295 Anthony Downs, An Economic Theory of Democracy, 74

296 Anthony Downs, An Economic Theory of Democracy, 83 - 84; 218 - 219; 237
} 
influence in the political sphere than others. ${ }^{297}$ Downs also talks about the use of ideology in political parties, which ties into Plato's worry over the use of rhetoric. ${ }^{298}$ Downs concludes that true political equality is actually impossible as long as uncertainty exists, there is a division of labor, and men act "rationally." ${ }^{299} \mathrm{He}$ states that this is because rational actors do not see the lot of time and effort needed to make sure that oneself is well-informed as worth it when the government will continue to work anyway and parties will continue to cater to their interests. ${ }^{300} \mathrm{In}$ this regard, Anthony Downs reinforces these philosophers' concept of the ease of voter manipulation. This discussion will continue in the Effects section below when addressing decisions made by the electorate.

Moving on from this, Aristotle and Plato also discuss democratic states as inevitably unhappy because of the lack intellectual virtues that lead to supreme happiness. While it seems safe to say that "a good life" and "fulfillment" can be found in other avenues, it seems at least a subject of interest to look at depression rates in the United States. The Centers of Disease Control and Prevention has an estimated 1 in 10 adults reporting that they are depressed, or have some symptoms of depression. ${ }^{301}$ While this excludes those who may be depressed but not realize it or refuse to admit it, and factoring in some methodological error, this is a high rate of depression. It is very interesting to note that those who were more likely to meet the criteria for major depression had the tendency to be unemployed or have a less than a high school education. At the very least, working can be argued to give a person a sense of fulfillment or purpose; it would seem logical that the unemployed or unable to work would feel unfulfilled. The criteria that those who are depressed are more likely to have less education rings true with this theory, but it is important to note that the lack of a high school diploma is highly likely to lead to

\footnotetext{
297 Anthony Downs, An Economic Theory of Democracy, 93 - 94

298 Anthony Downs, An Economic Theory of Democracy, 140 - 141

299 Anthony Downs, An Economic Theory of Democracy, 258 - 259

300 Anthony Downs, An Economic Theory of Democracy, 273 - 274

301 Centers for Disease Control and Prevention. "An Estimated 1 in 10 U.S. Adults Report

Depression." Last updated March 31 st 2011. <http://www.cdc.gov/features/dsdepression/>
} 
unemployment in the current environment. Separating these factors would be difficult.

Turning away from the subject of depression, it seems prudent to address Plato, Aristotle, and Thucydides' insistence upon the factional conflicts between the wealthy and the poor. Even the writers of our constitution and the succeeding individuals in power were very concerned about factional conflict, though it was a broader concept having less to do with wealth. Plato sees this conflict as more of an intricate part of democratic reality because the change from oligarchy to democracy causes an almost rabid animosity towards those who are wealthy. At the very least, the "we are the 99\%" movements of recent can be surmised as proving elements of this conflict as alive and well. Some of the themes of the "99\%" movement could been seen as exemplifying some of these characteristics of animosity, and stopping anyone on the street will generally yield results of at least irritation towards those who are more well off. However, Plato's conception of poor democratic citizens leeching money away from the wealthy to support their own lazy lifestyles does not seem quite correct considering the above statements about the rich having more sway in government than the poor. In counter, there are arguments, such as the "welfare moms" debate, that point out those who take advantage of the system. This could be interpreted as proving Plato's theory here correct, though in reality social welfare comes from everyone's taxes and not just the rich. Aristotle's conception of the conflict between the wealthy and the poor is more clear-cut, though he sees this conflict as causing revolutions between oligarchy and democracy. Thucydides continues this thought process in seeing the change back and forth between oligarchy and democracy in Athenian governance. This is where American exemplification of some of the characteristics of oligarchy starts to indicate a larger concern. In conclusion, there are elements of this tension between the two factions, but not the outright hatred that Plato describes.

For the final descriptive piece, Thucydides' identity of democracy being selfinterested could conceptually be tied to the common messages of "not in my back yard" and other slogans that populate American ideology. Self-interest can also be as interconnected with self-profit, which is a major theme in capitalist America. 
Important to remember is that all states practice some measure of self-interest; they have to, in order to survive in the first place. Yet it is interesting to note that on the opposite spectrum of this idea of self-interest, Thucydides' conception of Spartan focus on "morality" also is applicable to America. After all, American concern with "justice" is a constant message in international relations with other states; something that Thucydides describes was not part of Athenian make-up. This again returns to American similarity to ancient definitions of oligarchy. What does this even mean, that the United States has so many elements in common with the ancient definitions of oligarchy? Does it even matter, since these definitions were made so long ago in a time unlike ours? Before delving into these questions, this paper will first address the other two sections that have been used so far for comparative analysis.

\section{Causes and Conditions}

To recap, the causes and conditions of democracy that Plato, Aristotle, or Thucydides describes are as follows: formation due to a revolution, usually in reaction to an oligarchic regime; protection from conquest, for Athens specifically this was due to poor soils; the formation of an allied group or empire due to external threat; democratic development within a culture of warfare; democracy developing due to a rise in populations; and this section will end by addressing Aristotle's factors of revolution and looking to see if similarities exist within the United States.

First off and most obviously, the democracy of the United States did come about because of a revolution. In this regard Aristotle and Plato are correct. However, they see this revolution as a reaction to an oligarchic regime, when it is pretty safe to say the United States revolted from a monarchic regime. Also, Plato and Aristotle see this revolution an internal shift of power rather than external against another country. The details are off, but the concept of democracy forming from revolution still stands. In comparing Thucydides' conditions of Athens forming to America, it is first obvious that America did not develop in a barren land that had infertile soil. America was described as a haven of flourishing land, even compared to the Garden of Eden in biblical literature. However, an entire ocean separated 
America from the rest of the "civilized" nations, which made conquest more difficult. This is Thucydides' point in describing Attica's barren soil; that Attica was protected from conquest because it was not valuable. In this regard both Attica and America had protections that made conquest more difficult. It could be argued that because of this, both Attica and America were able to develop a culture of freedom and independence.

An additional parallel is found in the description of the Athenian empire of allies being built because other countries went to Athens for aid during the Persian Wars. There is an interesting comparability of this to overseas nations coming to America for help during the World Wars. It could safely be said that other nations came to the United States for aid because of its relative strength and wealth, for help defeating the invading regimes. This is especially clear in WWII. As for the ideological attributes of honor, self-interest, and fear, these elements can also be seen. Out of a sense of honor on the behalf the President the United States engaged in these wars, and out of self-interest was supplying arms and loans to allied regimes. It would also not be a stretch to say that the United States was galvanized into entering WWI because the attack on Pearl Harbor evoked fear and a sudden self-interest into doing so. Thucydides' description of Athens developing in a climate of continuing conflict because of Persia and the tension with Sparta is another parallel. There is definitely something to be said for the 7 wars the United States has engaged in the past century, as well as it's continual self-description of "the world's police force." These are the elements of Athenian rise to power.

It could also be said that the United States came about through a rise in populations. At the very least, the influx of refugees into Attica has a parallel story with the influx of pioneers to America, though it is safe to say that Native Americans were much less happy about this state of affairs. Another parallel could be drawn between the rise of populations in America and the evolution of the governing bodies. After all, the United States was fashioned in the framework of a republic but has evolved into more of a democracy. It could arguably be said that the original United States was like Aristotle's polity-like institution but growth in population caused this to be too difficult and evolved into a democracy. There probably are, of 
course, many other factors that actually play into this evolution, but this paper will not be delving into this deeper.

The increase in population also ties with another one of their conclusions. As populations increase without the increase of representatives in government, it has led to more drastic ratios and arguably much less representation. People become discouraged to participate in politics as it becomes harder and harder to reach representatives and be heard, so those with particular clout or know-how have more influence over representatives than others will. This concentration of those involved in politics either having clout or know-how seems to lead to the danger of control by those with particular agendas. Plato's concern with tyrants arises here as a theoretical problem, though his simplistic conclusions for democracy are complicated by the institutions in place to help prevent tyranny in the United States. As mentioned before, the framers of the United States constitution were influenced by concerns for tyranny, so perhaps these conclusions here are somewhat altered. With the structures in place to prevent both individual and majority tyranny, a change to an oligarchic structure seems to be a larger problem. This is not to say that the problem or threat of tyranny is any less valid or is not an issue of great concern.

To conclude this section on causes and conditions, this paper will be reviewing Aristotle's conceptions of what causes revolutions and looking at contemporary examples in the United States. As mentioned before, Aristotle writes that in revolutions people aim for equality or superiority, which seems like a common sense conclusion. The American Revolution was justified through the former aim, and all recent calls in the United States are usually in the context of some inequality perceived. As for Aristotle's hypothesis that conflict is engaged in because of profit, honor, or avoidance of punishment, recent examples of those who perceive an inequality often claim they are being punished or harmed unjustly. Fear, superiority, contempt, disproportionate growth of a part, electioneering, neglect of small things, and dissimilarity are Aristotle's general factors of what often causes a revolution. Fear could be said exists in the general public over concerns for the economy or government overstep. It would not be a far stretch to say that the 
electorate sees politicians as viewing themselves are superior, though whether or not politicians actually do see themselves as superior is a whole different basket of worms. Contempt is easily bred in this climate, and this paper has already mentioned a negative view towards those who are wealthy and in power. Disproportionate growth can be seen in the fact that United States GDP income growth is found mostly in the highest income brackets, with the lower income brackets seeing little or no change in real income. ${ }^{302}$ Electioneering, or campaigning - well, obviously that's an inherent part of American culture. Yet as earlier discussed, Aristotle's concern with electioneering probably stems from his worry over rhetoric and tyranny. While the safeguards written into our constitution - for example, short office terms - are protections against this tyranny, there is still room for pause as many campaign promises are not fulfilled. Obviously there are many complications involved in the fulfillment of campaign promises, considering the unwieldy nature of American government, and no politician will be elected through promising nothing. The danger arises when considering what else the public could consider as just a part of reality that cannot be changed.

Next, for the neglect of small things, pinpointing the cases of this happening is a hard thing to prove considering the size of the United States; but perhaps that proves Aristotle's point exactly, as things so easily slip through the cracks in managing a country this large. As for dissimilarity, the United States is theoretically built on diversity and freedom of choice; dissimilarity can be seen everywhere as different views, opinions, and backgrounds all are allowed to flourish. Yet even though the United States seems to have these elements that Aristotle describes, a more important question may be: how much of how many of these elements are needed for a revolution to form?

\footnotetext{
302 Daphne T. Greenwood and Richard P. F. Holt, “Growth, Inequality and Negative Trickle Down" Journal of Economic Issues XLIV (June 2010): 404; this article illustrates that the "real income" disparity between income quintiles has dramatically increased since about 1980 . This article argues that because of this the concept of "positive trickle down," which created economic stability in wages, income and wealth between 1950 and 1970, is no longer valid and has in fact become "negative trickle down," exacerbating income inequality.
} 
As for the specific factors for democracy leading to a revolution, Aristotle wrote that it forms because of wanton behavior of popular leaders; either harassing property owners into causing them to form an alliance against, or because popular leaders end up provoking the majority into revolting. The first version of this revolution seems unlikely because of the majority of wealth-holding individuals in power who are most likely not going to provoke their peers. However, it is true that there have been complaints and different kinds of threats if excessive taxation or hardship were to come on certain corporations or businesses. Corporations, for example, have threatened leave the United States all together; though Aristotle's conception of this is more of an alliance of property owners against the state, not leaving the state all together. As for the second kind of revolution, that seems more typical of the United States considering all the rumblings and frustrations. Both Congress and President Obama are not looked upon kindly at the moment; there is a legitimate claim that at some point opinion will be so negative a revolution will be provoked. Yet again the question could be asked, how much of these conditions need to be had before Aristotle perceives a revolution forming? Aristotle does not really answer these questions, so it is difficult to figure out where exactly the United States stands on the issue of revolution. At the very least, the United States has an alarming amount of Aristotle's factors for revolution.

As a final note, Aristotle also writes that democracies undergo revolutions from "traditional" democracy to the "most recent sort." While this a bit ambiguous as to what he means in his own time, it is interesting to note that he perceives the evolution of democracy even then. Recall from before that the definition and interpretation of democracy is an evolving form. Who knows where it will lead to next.

\section{Effects and Lessons}

This section will be concluding the analysis by directly comparing the philosopher's effects and lessons of democracy to trends in the United States. This section will look at the problems of an uninformed electorate, individual tyrants and tyranny of the majority, the United States democracy changing into oligarchy, the 
overextension of democracy in war, and will conclude by applying the lessons that these philosophers give for democracy.

The concern over the United States having an informed and educated electorate is as old as the regime itself; the question of whether or not American citizens are in fact politically ignorant has been proven as an unfortunate reality. Richard Shenkman's Just How Stupid Are We? A report on "the truth about the American voter" depicts through studies and tests the lack of knowledge that American voters have about basic political facts. ${ }^{303}$ Larry Bartels, in his article "The Irrational Electorate," responds to Shenkman's book by furthering this discussion to ask: so what? Bartels asks whether or not it really matters that American citizens know facts such as "how long a senate term is" or if they can "name the secretary of defense." By the end of the article he concludes that yes, not only does this ignorance cause the electorate to vote against their own interests, but the difference between informed and uninformed voters have major effects on election outcomes. ${ }^{304}$ In another one of Larry Bartel's articles, “Is 'Popular Rule' Possible? : Polls, Political Psychology, and Democracy," he shows through survey data how voter opinion changes depending on the context or the manipulation of the questions, revealing a concerning lack of consistency or understanding. ${ }^{305} \mathrm{He}$ seems to take a misanthropic approach and throws out the idea of voter rationality all together. Taking this conclusion, he challenges the concept that democracy is a "consistent normative basis for evaluating policy" at all and argues that the current view of democracy is "fundamentally unrealistic."

This view of democracy has some deep roots in the scholarship. Gabriel Almond, a famous political scientist of the Cold-War era, writes that United States citizens only care for their private pursuits and are not concerned with governing. He writes in his book The American People and Foreign Policy that American citizens spend all of their energy for personal gain, leaving them unable to expend the

\footnotetext{
303 Rick Shenkman, Just How Stupid Are We? A report on "the truth about the American voter (New York: Basic Books, June 2008)

304 Larry Bartels, “The Irrational Electorate," Wilson Quarterly 32, (2008): 44 - 50

305 Larry Bartels, "Is 'Popular Rule' Possible? : Polls, Political Psychology, and Democracy," The Brookings Review 21 (2003): 12 - 15
} 
energy needed to educate themselves and become involved in civil affairs. ${ }^{306} \mathrm{He}$ describes that the average citizen does not completely understand current events, only listens for the social "cues" that tell them how they are supposed to feel or act. Almond even goes so far as to recommend that the majority of citizens not be given full information at all, simply be given these emotion "cues," and then he continues on to argue that a social elite of educated and concerned citizens should be trained and raised to be governors. ${ }^{307}$ This is all in the context of fighting the "problem of communism," but the idea posed still stands. This paper will not be going into the structures that could possible "control" or "direct" the masses; this paper is designed to find solutions or answers to the problem of corruption in democracy, and in essence the control of the public can be considered corruption. This paper will leave the question of whether or not democracy is a realistic form of government to other, more capable hands.

Plato's tyrants do not exist in the United States, though some would argue otherwise. To them, it could be said that this is an insult to the people who suffer, or suffered, under the tyranny of places such as Tunisia, Egypt, and Syria. Corruption may exist in the United States but it is not to the extreme discussed in Plato's writings. The militarization of the police and confrontations with citizens could be paralleled to Plato's notion of a tyrant having its own private army to terrorize citizens, but it does not seem to be to that extreme. The possibility and generally trend of current actions do make this concerning. However, we cannot discredit the awareness of the framers of the United States constitution in understanding these inherent risks, and taking steps to attempt to prevent such happenings. While not perfect, it does skew the results of direct theory of democracy application. As for the concern of tyranny of the majority, the current winner-takes-all structure of the electoral process could be said to exemplify this problem. After all, if one party (Democratic or Republican) wins a majority by even $1 \%$ in a particular case, the

\footnotetext{
306 Gabriel Almond, The American People and Foreign Policy (New York: Frederick and Praeger, Inc., 1963), 49, 53, 69

307 Gabriel Almond, The American People and Foreign Policy, 232 - 235
} 
conclusion may look like $49 \%$ are not heard. This can also be seen in situations involving minorities, where the majority can drown out the interests of the few.

United States similarity to oligarchy is a bit concerning. With the more affluent in power, the education inequality giving some people power over others, and the tensions rising between the more affluence and the less, Aristotle's theory of oligarchy begins to look very real. Of course, this is not surprising to people like Jeffrey Winters, who as mentioned already, already sees the United States as a civil oligarchy. Aristotle would suggest a strong middle class as the remedy to prevent a continuous cycle of revolution between the two regimes. It is of interest to note that as he suggests this, there are has been concern over the decline of the middle class in the United States, ${ }^{308}$ even recognized in the political sphere. This trend of decline and concern for the decline can be traced back to the 1990's, though some scholars state this decline began in the 1960's with the New Deal. ${ }^{309}$ It would be interesting to see whether or not tensions between the wealthy and the poor have increased since this time, as Aristotle predicts.

Moving onto the topic of war, it can also be argued that as Athens engaged in continual war, the United States has engaged in continual war and conflict. Counting officially declared wars, the United States has engaged in six major wars in the $20^{\text {th }}$ and $21^{\text {st }}$ century. This is not counting the Cold War, conflicts in the Banana Republic, and our interventions in many countries in the Middle East and Northern Africa. Continuing down this path, as Athens alienated many allied countries, it could be said that the United States is alienating many countries. The situations are obviously different, as Athens was intent on reclaiming "its" territory and the United States has taken on more of a criminal justice role in being the world's police. Yet many of the criticisms leveled at Athens for being overly oppressive have also been leveled at

\footnotetext{
308 Nan Mooney, (Not) Keeping Up With Our Parents: the decline of the professional middle class (Boston: Beacon Press, 2008); Elizabeth Warren and Amelia Warren Tyagi, "The Two-Income Trap: Why Middle-Class Mothers and Fathers Are Going Broke (With Surprising Solutions That Will Change Our Children's Futures)" Michigan Law Review 103 (May 2005): 1273 - 1294; Clive Cook, et all, The Middle Class ed. David Haugen, Susan Musser, and Vickey Kalambakal (Detroit: Greenhaven Press, 2010) ${ }^{309}$ Frederick R. Strobel, Upward Dreams, Downward Mobility: The Economic Decline of the American Middle Class (Lanham: Rowman \& Littlefield Publishers, 1993)
} 
the United States. There is a lot of anti-American sentiment in the world. There are of course other factors involved with the growing criticism towards the United States, but the element of hostility towards the American use of warfare is a similarity to Athens.

It also seems important to note that as Thucydides describes the degradation of morality in the face of war, many have noted the growing trend of American desensitization towards war and destruction. Lieutenant Colonel Dave Grossman writes in his book On Killing, that not only are soldiers conditioned in order to accept and be comfortable with killing, but that American society as a whole is undergoing a conditioning process through our media. ${ }^{310}$ Grossman writes that he sees a trend between violent behavior in society and similar processes in general society that are used in the military to enable killing. ${ }^{311}$ He specifically uses violent television, movies, and videogames to draw similarities between military conditioning and what someone goes through when engaging in these violent media activities. ${ }^{312}$ He writes that as children are losing role models, they are more susceptible to violent tendencies and finding authority figures and family in gangs. ${ }^{313}$ Grossman concludes his book by saying we are on "the road to ruin," and we must re-sensitize ourselves to war and killing, to remember compassion, and turn off the kill switch. ${ }^{314}$ This can be seen as exemplifying Thucydides' cycle of demoralization in the face of war.

For the conclusion of this section, it becomes apparent that the lessons that can be taken from this analysis are themes that have been known since the inception of America. Many, if not all, of us have heard the phrase that a functioning democracy must have a well-informed electorate. To battle the problems inherent in the democratic structure, there must be quality, in-depth education for all. It would

\footnotetext{
310 Lieutenant Colonel Dave Grossman, On Killing: The Psychological Cost of Learning to Kill in War and Society (New York: Little, Brown and Company, 1996), 299;

311 Lieutenant Colonel Dave Grossman, On Killing, 302

312 Lieutenant Colonel Dave Grossman, On Killing, 308 - 311; 314 - 316; 319 - 322

313 Lieutenant Colonel Dave Grossman, On Killing, 319 - 322

314 Lieutenant Colonel Dave Grossman, On Killing, 323 - 332
} 
solve so many of the problems that exist within the democratic structure, from the electorate voting against their own interests to fostering compassion for differences. Aristotle would also argue that the citizenry must have an understanding of how democracy degrades, as to understanding how to prevent this collapse. It would also seem appropriate to argue for a strong, rigorous media that was accountable for what it reported on. In this way citizens would able to gather facts and make informed decisions; the original purpose of the media.

It also seems very important that there is a return to strength for the middle class in the United States. Thankfully, many people seem to realize this and are working to return the flourishing middle class to the United States. Yet economic inequality is also increasing in the United States, as was mentioned above. There must be a way to return our economic stability without increasing the inequality or phasing out the importance of the middle class.

It was also understood, even from the beginning of the United States, that it was important to guard against factional conflict. A strong middle class relieves the conflict between the rich and the poor, but I would also argue that something must be done to solve the conflict between the Democratic and Republican parties. The awareness of this problem is thankfully already circulating, yet something like this is obviously easier said than done. Aristotle warns to guard against factional conflict because it will start the rivalries and animosities that bring about civil warfare. With the diversity that flourishes in democracy, this problem must be carefully watched and measures taken to try to ease communication and cooperation between the diversification that is seen. In this, education can form compassion and understanding between the varieties of people. It seems that every problem spoken of here, in one way or another, leads back to education and being informed. 


\section{Conclusion}

We have now reached the conclusion of this analysis. ${ }^{315}$ Yet what does it really tell us? The question of corruption in the United States is still somewhat unclear; while it is true that no real tyrants exist in the United States, the unease that many feel does not go without merit. The United States exemplifies many of the issues that these philosophers warn against. Yet the United States is not a clear example of democracy in the first place because its creation entailed many safeguards against these problems, as well as originally being created in the form of a Republic.

The hard part comes when realizing that the solution has been there all the time, but it requires a level of civic engagement that most people in the United States are unwilling to give. It requires a critical attention to creating quality education - even reform - and a vigorous accountability for both our media and our politicians. The paradox arises when realizing that democratic citizens are given the option whether or not to participate in governing, but in essence a democracy fails when citizens decide to opt out.

The surprising conclusion was the United States similarity to oligarchy. Yet scholars of both ancient and contemporary are not surprised by this conclusion. Thucydides describes the wealthy of Athens as the cause of the government turning oligarchy and the army as the instigators of change back to democracy (or something more democratic). The military in the contemporary often works with dictators and corrupt governments to suppress and terrorize citizens (Thucydides does describe the military supporting certain changes because of the pay raises they would receive). With this reality and the concerning trend of the police lashing out at citizens, it seems unlikely the army would change the United States back to a democracy if such a change were to occur. Jeffrey Winters writes that the United

\footnotetext{
315 Another fascinating analysis can be found in Loren J. Samons II, What's wrong with democracy? : From Athenian practice to Athenian Worship (Berkeley: University of California Press, 2004); in this book Samons also develops a critique of modern democracy using its philosophical foundations, using many of the same philosophers such as Socrates (Plato) and Thucydides.
} 
States is already an oligarchy; if this is so, then American citizens must decide if this acceptable, and whether or not they want to muster the effort to change.

Unfortunately people have shown the tendency to only change when they have to, so it may be a while before we see the energy needed for this change.

There is a sadness that comes along with the realization that we as a people have always known what our duty is as democratic citizens, but most are unwilling to expend the energy to do so. From this perspective it is hard to see how democracy will ever succeed longer than the collective memory of the populous. Yet perhaps this is not sadness at all. Perhaps it is the nature of democracy to survive in cycles, to live, age, and die as we do - and then be reborn. As faulty as humanity may be, we are also spirited, adaptable, and constantly searching for something better. It is in this search that our saving grace may be found. 


\section{BIBLIOGRAPHY}

Almond, Gabriel. The American People and Foreign Policy. New York: Frederick and Praeger, Inc., 1963.

Aristotle. The Politics. Translated by Carnes Lord. Chicago: University of Chicago Press, 1985.

Aristotle. Nicomachean Ethics. Translated by Roger Crisp. Cambridge: University of Cambridge, 2000.

Bartels, Larry "Income Inequality and Political Representation," in the Princeton University database for Bartel's working papers, <http://www.princeton.edu/ bartels/economic.pdf, written August 2005>

Bartels, Larry. “Is ‘Popular Rule’ Possible? : Polls, Political Psychology, and Democracy," The Brookings Review 21 (2003): 12 - 15

Bartels, Larry. “The Irrational Electorate.” Wilson Quarterly 32, (2008): 44 - 50

Bloom, Allan David. The Closing of the American Mind: how higher education has failed democracy and impoverished the souls of today's students. New York: Simon and Schuster, 1987.

Brunner, Eric, Stephen Ross, and Ebonya Washington, “Does Less Income Mean Less Representation?" National Bureau of Economic Research Working Paper Series Paper No.: 16835 (Feb. 2011; Revised Jan. 2012)

Carnes, Nicholas. "By the Upper Class, for the Upper Class? Representational Inequality and Economic Policymaking in the United States." PhD diss., Princeton University, 2011.

Ceaser, James W. “Demagoguery, Statesmanship, and the American Presidency.” Critical Review: A Journal of Politics and Society 19, (2007): 257-298

Center on International Education Benchmarks. "Finland: System and School Organization." Last accessed June 6, 2013. <http://www.ncee.org/programsaffiliates/center-on-international-education-benchmarking/top-performingcountries/finland-overview/finland-system-and-school-organization/> 
Center on International Education Benchmarks. "Hong Kong: Instructional Systems." Last accessed June 6, 2013. <http://www.ncee.org/programsaffiliates/center-on-international-education-benchmarking/top-performingcountries/hong-kong-overview/hong-kong-instructional-systems/>

Center on International Education Benchmarks. "Singapore: Overview." Last accessed June 6, 2013. <http://www.ncee.org/programs-affiliates/centeron-international-education-benchmarking/top-performingcountries/singapore-overview/>

Centers for Disease Control and Prevention. "An Estimated 1 in 10 U.S. Adults Report Depression." Last updated March 31 2011. <http://www.cdc.gov/features/dsdepression/>

Centers for Disease Control and Prevention. "Overweight and Obesity." Page last updated August 13 $3^{\text {th }}$ 2012. Last accessed May 16, 2013. <http://www.cdc.gov/obesity/data/adult.html>

Central Intelligence Agency. "A Spotlight on World Obesity Rates." Last updated November 20 ${ }^{\text {th }}$ 2012. Last accessed May 16, 2013. $<$ https://www.cia.gov/news-information/featured-story-archive/2012featured-story-archive/obesity-according-to-the-world-factbook.html>

Chan, Michael D. Aristotle and Hamilton on Commerce and Statesmanship. Columbia: University of Missouri Press, 2006.

Cohen, David. "Justice, Interest, and Political Deliberation in Thucydides." Quaderni Urbinati di Cultura Classica 16 (1984): 35 - 60

Cook, Clive, Brian Purnell, Christian E Weller, David Brooks, Mary Agnes Carey, Rebecca Adams, Pat Barile, Paul Krugman, Rodney Smith, Elizabeth Warren, Amelia Warren Tyagi, Stephen Zacks, Kathe Newman, Elvin Wyly, Naomi Schaefer Riley, Lisa Arrastia, Joel Russell, Jennifer Wheary, Kris Marsh, Maya Payne Smart, Kay S Hymowitz, Tom Eblen, Steve Chapman, Lou Dobbs, Gabor Steingart, Robert B Reich, Barack Obama, Newt Gingrich, and Peter Ferrara. The Middle Class ed. David Haugen, Susan Musser, and Vickey Kalambakal. Detroit: Greenhaven Press, 2010. 
Corlett, J. Angelo. “Interpreting Plato's Dialogues.” The Classical Quarterly 47 (1997): $423-437$

Dahl, Robert. Democracy and its Critics. New Haven: Yale University, 1989. Downs, Anthony. An Economic Theory of Democracy. New York: Harper and Brothers, 1957.

Finley, M. I. Aspects of Antiquity. New York: The Viking Press, 1968.

Gilens, Martin. Affluence and Influence. Princeton: Princeton University Press, 2012. Greenwood, Daphne T. and Richard P. F. Holt. “Growth, Inequality and Negative Trickle Down." Journal of Economic Issues XLIV (June 2010): 403 - 410 Institute for Addiction Medicine. "Statistics." < http://www.ioam.org/statistics.html> International Center for Prison Studies. World Prison Population List, $9^{\text {th }}$ edition (May 2011), by Roy Walmsley. Report. Last accessed May 30, 2013.

Kagan, Donald. The Great Dialogue: History of Greek Political Thought from Homer to Polybius. New York: The Free Press, 1965.

Kalyvas, Andreas. "The Tyranny of Dictatorship: When the Greek Tyrant Met the Roman Dictator." Political Theory 35 (Aug. 2007): 412 - 442

Ladson-Billings, Gloria. "From the Achievement Gap to the Education Debt: Understanding Achievement in U.S. Schools." Educational Researcher 35 (Oct. 2006): $3-12$

Lane, Melissa, "Ancient Political Philosophy", The Stanford Encyclopedia of Philosophy (Fall 2011 Edition), Edward N. Zalta (ed.), <http://plato.stanford.edu/archives/fall2011/entries/ancient-political/>.

McGregor, Malcolm F. “The Politics of the Historian Thucydides." Phoenix 10 (1956): $93-102$

Mooney, Nan. (Not) Keeping Up With Our Parents: the decline of the professional middle class. Boston: Beacon Press, 2008.

National Center for Education Statistics. "Mathematics Achievement of Fourth- and Eighth-Graders in 2011." < http://nces.ed.gov/timss/results11_math11.asp> National Center for Education Statistics. "PIRLS 2011 Results." <http://nces.ed.gov/surveys/pirls/pirls2011.asp> 
National Center for Education Statistics. "Science Achievement of Fourth- and Eighth-Graders in 2011." <http://nces.ed.gov/timss/results11_science11.asp>

Ober, Josiah “Thucydides' Criticism of Democratic Knowledge," in Nomodeiktes: Greek Studies in Honor of Martin Ostwald ed. Ralph M. Rosen and Joseph Farrell, 81 - 98. Ann Arbor: University of Michigan Press, 1993.

Opensecrets.org. "2012 Presidential Race.” <http://www.opensecrets.org/pres12/> Oren, Ido. Our Enemies and US. Ithaca: Cornell University Press, 2002.

Orfield, Gary and Chungmei Lee. "Why Segretation Matters: Poverty and Educational Inequality." Harvard University, The Civil Rights Project (Jan. 2005)

Prescott, Carol A. Ph.D. and Kenneth S. Kendler, M.D. “Genetic and Environmental Contributions to Alcohol Abuse and Dependence in a Population-Based Sample of Male Twins." American Journal of Psychiatry 156 (1999): 34 - 40

Samons II, Loren J. What's wrong with democracy? : From Athenian practice to Athenian Worship. Berkeley: University of California Press, 2004.

Shenkman, Rick. Just How Stupid Are We? A report on "the truth about the American voter. New York: Basic Books, 2008.

Substance Abuse and Mental Health Services Administration, The. "2011 National Survey on Drug Use and Health." Last accessed May 16, 2013.

Thomas Pangle and Peter Ahrendsdorf, Justice Among Nations. Lawrence: University Press of Kansas, 1999.

Plato. Apology in The Last Days of Socrates. trans. Christopher Rowe. New York: Penguin Group, 2010.

Plato. Gorgias. ed. Robin Waterfield. New York: Oxford University Press, 1994. Plato. The Dialogues of Plato. Translated by Benjamin Jowett. London: Oxford University Press, 1953.

Plato. The Republic. Translated by Desmond Lee. New York: Viking Penguin Inc., 1987.

Strobel, Frederick R. Upward Dreams, Downward Mobility: The Economic Decline of the American Middle Class. Lanham: Rowman \& Littlefield Publishers, 1993. 
Thucydides. History of the Peloponnesian War. Translated by Rex Warner. New York: Viking Penguin Inc.

United Nations Office on Drugs and Crime. World Drug Report 2012 (United Nations publication, Sales No. E.12.XI.1) Last accessed May 16, 2013.

U.S. Census Bureau, Population Division, "Table 1. Monthly Population Estimates for the United States: April 1, 2010 to April 1, 2013 (NA-EST2012-01-413)" Released May 2013.

U.S. Census Bureau. "International Programs; Total Midyear Population for the World: 1950 - 2050," Last accessed May 21, 2013.

U.S. Department of Justice. Office of Justice Programs. Bureau of Justice Statistics. "Correctional Populations in the United States, 2011" (November 2012) by Lauren E. Glaze and Erika Parks.

Warren, Elizabeth and Amelia Warren Tyagi. "The Two-Income Trap: Why MiddleClass Mothers and Fathers Are Going Broke (With Surprising Solutions That Will Change Our Children's Futures)." Michigan Law Review 103 (May 2005): $1273-1294$

Whitehead, Alfred North. Process and Reality. New York: Free Press, 1979.

Winters, Jeffrey. Oligarchy. Cambridge: Cambridge University Press, 2011.

Winters, Jeffrey and Benjamin Page. "Oligarchy in the United States?" Perspectives on Politics 7, (2009): 731 - 751

Zuckert, Michael P., Jean Yarbrough, Garrett Ward Sheldon, Robert Dawidoff, Robert Booth Fowler, Joyce Appleby, James W. Ceaser. Thomas Jefferson and the Politics of Nature, ed. Thomas S. Engeman. Notre Dame: University of Notre Dame Press, 2000. 